IZA DP No. 6770

School and Drugs: Closing the Gap Evidence from a Randomized Trial in the US

Núria Rodríguez-Planas

July 2012 


\title{
School and Drugs: Closing the Gap - Evidence from a Randomized Trial in the US
}

\author{
Núria Rodríguez-Planas \\ $I Z A, I A E-C S I C$ \\ and Universitat Pompeu Fabra
}

Discussion Paper No. 6770

July 2012

IZA

P.O. Box 7240

53072 Bonn

Germany

Phone: +49-228-3894-0

Fax: +49-228-3894-180

E-mail: iza@iza.org

\begin{abstract}
Any opinions expressed here are those of the author(s) and not those of IZA. Research published in this series may include views on policy, but the institute itself takes no institutional policy positions.

The Institute for the Study of Labor (IZA) in Bonn is a local and virtual international research center and a place of communication between science, politics and business. IZA is an independent nonprofit organization supported by Deutsche Post Foundation. The center is associated with the University of Bonn and offers a stimulating research environment through its international network, workshops and conferences, data service, project support, research visits and doctoral program. IZA engages in (i) original and internationally competitive research in all fields of labor economics, (ii) development of policy concepts, and (iii) dissemination of research results and concepts to the interested public.
\end{abstract}

IZA Discussion Papers often represent preliminary work and are circulated to encourage discussion. Citation of such a paper should account for its provisional character. A revised version may be available directly from the author. 


\title{
ABSTRACT
}

\section{School and Drugs: Closing the Gap - Evidence from a Randomized Trial in the US ${ }^{*}$}

\begin{abstract}
We present evidence on how The Quantum Opportunity Program (QOP hereafter) worked in the US. While the program was regarded as successful in the short-term, in the long-run its educational results were modest and its effects on risky behaviors detrimental. Exploiting control group's self-reported drug use while in school, we evaluate whether the program worked best among those with high-predicted risk of problem behavior. We find QOP to be extremely successful among high-risk youths as it managed to curb their risky behaviors during high-school and, by doing so, it persistently improved high-school graduation by 20 percent and college enrollment by 28 percent. In contrast, QOP was unsuccessful among youths in the bottom-half of the risk distribution as it increased their engagement in risky behaviors while in high-school. Negative peer effects are possibly an explanation behind these results. Finally, negative peer effects also seem to explain the longer-run detrimental effects of QOP on risky behaviors.
\end{abstract}

JEL Classification: $\quad$ C93, I21, I22, I28, J24

Keywords: mentoring programs, peer effects, risky behaviors, educational programs, randomized trials

Corresponding author:

Núria Rodríguez-Planas

Visiting Research Fellow

IZA

P.O. Box 7240

53072 Bonn

Germany

E-mail: rodriguez-planas@iza.org

\footnotetext{
* The Quantum Opportunity Program experiment study was conducted under Contract No. K-5547-500-80-30 from the U.S. Department of Labor and the Ford Foundation. The views expressed herein do not necessarily reflect the policies or opinions of the U.S. Department of Labor. This paper has benefitted from comments from Andrew Oswald, Aaron Sojourner, and Christopher Taber.
} 
Poor academic performance and engagement in risky behaviors are two of the most serious problems youths face today in the United States. Despite recent improvements, only 76 percent of young people graduated from high school in 2009 in the US, far from the OECD average of 82 percent. In addition, college completion among the 25- to 34-year-olds is also relatively low with the US ranking $15^{\text {th }}$ among 34 OECD countries (OECD in Figures, 2011). At the same time, the US also underperforms in terms of 13- to 19-year-olds' engagement in risky behaviors as it ranks $15^{\text {th }}$ among 30 OECD countries (OECD, 2009). ${ }^{1}$ Estimates from the 2010 National Survey on Drug Use and Health reveal that as many as 10 and 14 percent of children 12- to 17-years-old reported illicit drug and alcohol use in the past 30 days, respectively. As a consequence, a large sum of the United States' budget is devoted to improve the social and educational outcomes of youths. The U.S. Federal government alone allocated $\$ 14.5$ billion to Title I program, the largest program under No Child Left Behind, and over \$500 million to The Safe and Drug Free Schools Program in fiscal year 2009. ${ }^{2}$ In addition, many policy makers, practitioners and researchers have tried to develop programs whose main objective is to curb adolescents' problem behaviors such as drug use, and school dropout.

According to psychologists, there is a bidirectional relationship between risky behaviors and poor academic performance (Grant et al., 2011; Guttman et al., 2002; and Symons et al., 1997). Moreover, economists have found that engaging in a variety of risky behaviors leads to poor academic achievement (Yamada et al., 1996; Cook and Moore, 2000) and vice-versa (Sander, 1995a, b, de Walque, 2004; Kenkel et al., 2006; and Grimard and Parent, 2007; and Jensen and Lleras-Muney, forthcoming). Thus, an interesting and timely policy question given today's limited resources is to ask whether it is more effective to target adolescents with high-risk of problem behavior or those at the margin of socially behaving. Empirical assessment of this question has proven difficult for the following two reasons. First, the way

\footnotetext{
${ }^{1}$ This ranking is based on the following 3 indicators of risk taking: 15-year-olds who smoke regularly, 13- and 15-year-olds who report having been drunk on more than two occasions, and rates of birth to females aged 15 to 19 .

${ }^{2}$ These two programs aim at improving primary and secondary education of disadvantaged students and preventing violence and illegal use of tobacco, alcohol, and drugs by students, respectively.
} 
psychologists study risk taking relies on asking individuals to respond to hypothetical dilemmas under conditions designed to minimize emotional influences on decision making. However, as Steinberg, 2004, points out: "...in the real world the risky, or potential risky, situations in which adolescents find themselves are anything but hypothetical....and they most likely occur under conditions of emotional arousal." Second, non-experimental evaluations of remedial programs are likely to bias the results since the reasons for which individuals self-select into programs are likely to be correlated with the underlying determinants of their outcomes.

In this paper we avoid the latter problem by using data from a randomized experiment in which some low-performing high-school students from low-performing high-schools in the US were offered mentoring, educational services and financial rewards during the 4 years of high-school (plus one additional year in case students fell behind one grade) while others were not (the control group). ${ }^{3}$ In addition, because the data collection included 3 surveys conducted 5, 7 and 10 years after random assignment on four key domains-high-school, post-secondary education, labor market, and risky behaviors-, we are able to use the control group's self-reported drug use at age 19 to estimate predicted probabilities of problem behavior. We then evaluate whether the program was effective for two distinct groups defined by whether their predicted probabilities of drug use at age 19 was below or above the control group's median. As young women may have more self-discipline (Duckworth and Seligman, 2006), be more likely to delay gratification (Silverman, 2003), or have lower discount rates than young men (Warner and Pleeter, 2001), implying a differential heterogeneity effect in drug use, the assignment to the top- or bottom-half of the risk distribution is done separately by gender. ${ }^{4}$

The research design in this paper is based on comparison of youths with high(or low-) predicted chance of drug use who were randomly assigned to a treatment and control group when they first entered high-school in the Quantum Opportunity

\footnotetext{
${ }^{3}$ Enrollees who graduated from high-school on time received some mentoring and assistance in enrolling in post-secondary education or training between graduation and the end of the fifth year of the experiment.

${ }^{4}$ Because gender may lead to heterogeneity effects in programs effectiveness (Rodríguez-Planas, 2012), the analysis of the effectiveness of QOP was also done by gender. Results were similar to those presented in the main text, and available from the author upon request.
} 
Program (QOP thereafter) social experiment, which was implemented at 11 highschools across 7 sites in the United States. QOP's goals were to help youths graduate from high school and enroll in post-secondary education or training, and reduce risky behaviors. Students entering $9^{\text {th }}$ grade in September 1995, except for those with an $8^{\text {th }}$ grade point average (GPA) above the $66^{\text {th }}$ percentile, were randomly assigned within each school to a treatment group or a control group. It is thus, important to note that the program targeted disadvantaged youths from low performing schools, and thus its targeted population had major difficult barriers to overcome, such as, substance abuse problems, or broken families. Over five years, the treatment group was offered substantial cash awards and an array of support services including mentoring by fulltime social workers, academic tutoring and life skill activities. The control group was only eligible for standard youth programs offered in the community. The final sample for the QOP experiment consists of 1,069 students, 580 in the QOP group and 489 in the control group. ${ }^{5}$ Rodríguez-Planas (forthcoming AEJ: Applied Economics) has estimated the average effects of the program and found that while the program was regarded as successful in the short-term, in the long-run its educational results were modest and its effects on risky behaviors detrimental.

By analyzing whether the program worked best among those with high-predicted risk of problem behavior, this study shows that QOP was extremely successful in improving educational and behavioral outcomes for those most at risk, that is, youths in the top-half of the predicted drug use distribution. For this group, QOP increased high-school graduation by about 20 percent and college enrollment by 28 percent. Most importantly, these results persist over time, up to five years after the end of the program. Evidence shows that the program curbed risky behaviors (including substance abuse) among this group during high-school. QOP's mentors were social workers trained to identify and deal with youths' many structural barriers. They addressed any problems in any aspect of the treated youths' life, monitored their

\footnotetext{
${ }^{5}$ The final sample includes a slightly larger number of youths in the treatment group (580) than in the control group (489) by design of the evaluation sample, where it was decided that each site would have either 50 or 100 youths in the treatment group (with the exception of the Washington D.C. site, which had 80 youths). The design of the evaluation sample is thoroughly explained in Rodríguez-Planas (forthcoming AEJ: Applied Economics).
} 
progress, and advocated for them in matters pertaining to school, family, the juvenile justice system, and college. The mentor was expected to model appropriate behavior and attitudes, set disciplinary standards, and be continually available. Our estimates suggest that mentors succeeded in addressing treated youths' most severe problems at least while the program was operating, and that by doing so, they also succeeded in improving their high-school and college outcomes both in the short-, medium- and long-run. In contrast, we find suggestive evidence that QOP was unsuccessful among youths in the bottom-half of the distribution because it increased their engagement in risky behaviors while in high-school, and had no effect on educational outcomes in the short-, medium-, or long-run. The evidence presented is suggestive that negative peer effects may explain this lack of beneficial effects among this group. Finally, negative peer effects also seem to explain the longer-run detrimental effects of QOP on risky behaviors.

Recently, several researchers have found that targeting disadvantaged children before formal schooling begins promotes economic efficiency as the cognitive ability and character of children 0- to 5-years-old is the most malleable (Currie, 2001; Krueger and Whitmore, 2001; Heckman, 2000; Garces et al., 2002; and Carneiro and Heckman, 2003). In this paper we take a different approach and contribute to the debate over whether investments in the later stages of a child's development have positive payoffs. While other rigorous studies have evaluated interventions targeted to youths at a relatively late stage of schooling (Machin, McNally and Meghir, 2004; and Lavy and Schlosser, 2005; Angrist and Lavy, 2009; and Rodríguez-Planas, forthcoming AEJ: Applied Economics), this paper is (to the best of our knowledge) the first one to explore the effectiveness of an intervention when targeting adolescents based on the predicted probability of problem behavior. ${ }^{6}$ Our findings provide evidence that QOP may be closing the gap between those most at-risk and those at the margin, and the mechanisms through which this may be.

\footnotetext{
${ }^{6}$ To the best of my knowledge, Angrist and Lavy, 2009, are the only ones to analyze whether targeting based on the predicted or fitted chance of high-school matriculation certification is effective. Using a school-based randomization design offering cash incentives to all who passed their high-school matriculation certificate (Bagrut) in Israeli low-performing treated schools, the authors find that the experiment led to a substantial increase in certification rates for girls with high predicted Bagrut rates relative to other girls in the sample.
} 
This paper is organized as follows. The next section describes the program implementation, the evaluation framework, and the data. Section III analyzes the results, and section IV concludes.

\section{The Quantum Opportunity Program}

\section{A. Program Description}

QOP engaged treated students in: (i) developmental activities intended to develop their social and employment-readiness skills; (ii) community service activities intended to develop their sense of community membership; and (iii) educational services designed to improve their academic performance. Examples of such activities are displayed in Appendix Table A.1. These activities were to be performed after school and during one half day on the weekend. The full treatment consisted of 750 hours of services per year (equally distributed among the three different activities), which (if achieved) would have represented around three-quarters of the hours required for in-school instruction per year. ${ }^{7}$

To encourage participation, QOP offered financial incentives to treated students. First, they received $\$ 1.25$ for each hour devoted explicitly to educational activities, developmental activities (excluding recreational activities) and community service. Second, they were promised if they obtained a high school diploma or GED and enrolled in post-secondary education or training they would receive an amount equal to their total earnings. The treated youths received on average over $\$ 1,000$ after highschool graduation and enrollment in post-secondary education. This aspect of the financial reward was partly motivated by evidence that a $\$ 1,000$ reduction in college tuition increases college enrollment by about 4 percentage points (Susan Dynarski 2003).

${ }^{7}$ In 2000, the average number of instructional hours spent in public school by 15-year-olds was 990 hours (U.S. Department of Education 2005; Table 26-2). 
Case managers with prior expertise in social services were hired for the five-year period. ${ }^{8}$ Each had a caseload of only 15 to 25 treated students. The objective was to develop a highly personal, long-lasting connection with each youth that mirrored the relationship between a teenager and a nurturing, supportive older relative. Therefore, the case manager was instructed to focus on sustaining a strong relationship with the youth regardless of behavior, including whether the youth disengaged from the program, dropped out of school, became incarcerated, or moved out of the area. Case managers were also to manage the provision of supportive services to address personal, family and social barriers that might interfere with the treated student's ability to attend school and do well there. ${ }^{9}$

At almost \$25,000 per enrollee for the whole intervention, QOP was an expensive program. By comparison, the operating costs of the likewise-expensive Job Corps were approximately \$16,500 per participant in 1998 (Schochet, Burghardt, and McConnell 2008).

\section{B. Average Results}

This paper is closer to Rodríguez-Planas (forthcoming AEJ: Applied Economics) in that it analyzes the same randomized evaluation. Rodríguez-Planas estimates average effects of QOP and finds that the average beneficial effects of the program on highschool graduation were short lived, and that the program did not reduce risky behaviors during high-school. Although the program did managed to increase postsecondary education, many question whether the outcomes of the program warrant its intensity and high costs.

Since both psychologists and economists find evidence of a strong link between substance abuse and school performance, and given that QOP was mainly a mentoring program designed to identify and deal with students' many structural barriers-including substance abuse--, this paper analyzes whether the program had differential

\footnotetext{
${ }^{8}$ Most mentors stayed with the program for several years and many stayed for the entire five years of the experiment. Unfortunately, no information on sex, race or ethnicity of mentors was collected.

${ }^{9}$ These barriers could be addressed either directly by the case manager or by referral to a community resource, such as a substance abuse program or local agencies that provide housing, food, income support, or child care.
} 
effects according to whether treated students were in the top- or bottom-half of the predicted drug use distribution at age 19. By doing so we provide novel valuable evidence that QOP worked extremely well for those most at risk, and offer additional information on the mechanisms through which the program may have worked (or failed to do so).

\section{Evaluation Framework}

The estimates reported are intent-to-treat (ITT) effects that make no adjustments for remaining involved or service participation in QOP. They are computed from estimating the following equation:

$$
\mathrm{Y}_{i s t}=\alpha+\beta_{1} D_{i}^{\mathrm{T}}+\beta_{2} \mathrm{X}_{i s 0}+\delta_{s}+\varepsilon_{i s t}
$$

where $\mathbf{Y}_{\text {ist }}$ denotes an outcome variable for youth $i$ from school $s$ at time $\mathbf{t}, \mathbf{D}_{1}^{\mathbf{T}}$ is a dummy variable that takes value one if the youth belonged to the treatment group, and $\mathrm{X}_{\mathrm{is0}}$ is a vector of controls including an indicator for being 14 years old when entering ninth grade, an indicator for being over age 14 when entering ninth grade, an indicator for being in the middle third of the eighth-grade GPA distribution, an indicator for being in the top third of the eight-grade GPA distribution, an indicator for being black and an indicator for being Hispanic. ${ }^{10} \boldsymbol{\delta}_{\mathrm{s}}$ are school dummies, and $\boldsymbol{\varepsilon}_{\mathbf{j s t}}$ is the error term. $\beta_{1}$ measures the treatment effect of the program's impact on outcome Y. Many of the outcome variables included in this study are binary. In such cases, we estimate a linear probability model and report the marginal effect of $\mathbf{D}_{1}^{\mathrm{T}}$ for the impact of QOP on outcome $\mathbf{Y} .^{11}$ As in Rodríguez-Planas (forthcoming) we decided against clustering the standard errors at the school level, which was the unit of randomization, as we were concerned that clustering would under-estimate standard errors as the

\footnotetext{
10 Since treatment was assigned randomly, the insertion of these covariates improves estimation precision without affecting the consistency of the parameter of interest. Precision is improved because the inclusion of the covariates accounts for chance differences between treated and control groups in the distribution of pre-random assignment characteristics, as well as for non-random attrition in the followup surveys.

${ }^{11}$ We replicated our analysis using a Probit model and find very similar results.
} 
number of schools is limited. Clustering standard errors at the school-level does not affect the main results as shown in the robustness section.

The analysis focuses on several outcomes from four key families of outcomes, highschool, post-secondary education, labor market, and risky behaviors, measured at three different points in time. The results are presented separately for youths at the bottomand top-half of the predicted drug use at age 19 distribution. To address the problem of multiple inference, we follow Kling, Liebman, and Katz 2007 and construct a summary index, $\mathbf{Y}^{*}$, as the unweighted average of all standardized outcomes within a family. That is, $\mathrm{Y}^{*}=\frac{\sum_{\mathrm{k}} \mathrm{Y}_{\mathrm{k}}^{*}}{\mathrm{k}}$, where $\mathrm{Y}_{\mathrm{h}}=\frac{\mathrm{Y}_{\mathrm{k}}-\mu_{\mathrm{k}}}{\sigma_{\mathrm{k}}}$. Let $\mathrm{Y}_{\mathrm{k}}$ be the $k^{\text {th }}$ outcome of $\mathbf{K}$ variables within each family, with the sign for adverse outcomes (substance abuse, crime, welfare) reversed, so that a higher value of the normalized measure represents a more "beneficial" outcome. Standardization is performed using mean $\left(\mu_{k}\right)$ and standard deviation $\left(\sigma_{k} k\right)$ for the control group. The summary indices presented in this paper are constructed using the same specific outcome variables as in RodríguezPlanas.

To classify youths by their risk of problem behavior we use a predictive regression that models the probability of problem behavior as a function of school dummies and individual covariates. The predictive model is:

$$
Y_{\text {is }}=\alpha_{0}+X_{\text {is } 0}^{\prime} \beta+\delta_{s}+\varepsilon_{\text {is }}
$$

where $X_{\text {is } 0}$ and $\delta_{s}$ are as in equation (1), and $Y_{\text {is }}$ a dummy variable that takes value one if the youth reported having used drugs in the past 30 days during the first survey, which was collected at age 19. Since model (2) is used to classify treated and control youths, we first estimate it separately for males and females using only youths from the control group. Appendix Table A.2 reports the coefficients estimated using equation (2). Males are more likely to have problem behavior than females as shown by the descriptive statistics at the top of Appendix Table A.2. We then estimated equation (1) using the following subgroup-classification scheme: we used the fitted values from model (2) to divide students into roughly equal-sized groups, those in the top and the bottom of the predicted-risk distribution. This classification was done by gender, as 
the predicted drug use during high-school of females was considerably lower than that of males. ${ }^{12}$

\section{The Data and Descriptive Statistics}

The data for this study come from baseline information collected prior to random assignment, program implementation and participation, high-school transcripts, math and reading achievement tests conducted 4 years after random assignment, and three surveys conducted 5, 7 and 10 years after random assignment. Transcript data were collected 5 years after random assignment from all high-schools treated and control group individuals attended.

Table 1 reports means and differences in means by treatment status for our baseline variables. ${ }^{13}$ Columns 1 to 3 refer to the whole sample. They show that the sample is roughly equally divided between boys and girls. The median age of students was 14 when random assignment took place. The sample consists mainly of minority students: about two thirds are African-American and about one fourth are Hispanic (black or nonblack). There are no significant differences by treatment status.

Columns 4 to 9 present treatment and control means and differences for those in the top- and bottom-half of the predicted drug use distribution. Among youths in the bottom-half of the predicted risk distribution we observe that treated youths are less likely to be males and in the middle tier of the $8^{\text {th }}$ grade GPA distribution than those in the control group. To account for these differences, estimation of equation (1) controls for all baseline characteristics as explained above.

Control response rates and treatment-control differences for the achievement test completion and the follow-up surveys are displayed in Table $2 .{ }^{14}$ The response rate to the achievement tests and the first telephone survey was 80 percent for the control group. The response rates to the second and third telephone surveys were 69 and 72

\footnotetext{
${ }^{12}$ For males, those with a predicted probability of drug use above 35 percent where classified in the tophalf of the risk distribution, whereas the threshold for females was 17 percent.

${ }^{13}$ As no baseline survey was collected, the pre-program information available is limited. However, the main baseline variable that is missing (compared to similar evaluations) is parent's education level. Fortunately, this variable is likely to be correlated with pre-program GPA, which we do have.

${ }^{14}$ All individuals from the treatment and control group were surveyed, regardless of whether they failed to respond in one of the earlier surveys
} 
percent for the control group, respectively. Attrition was higher among control group members than among treatment group members in all but the third telephone survey. The differential response rate between the treatment and control groups is 7 percentage points in the first telephone survey, 10 percentage points in the second telephone survey, and a statistically insignificant 3 percentage points in the third telephone survey. After dividing the sample by the predicted probability of drug use at age 19 we observe that most of the attrition differential between treated and control youths is driven by those in the top-half of the risk distribution. As these are the most difficult youths, higher attrition among them is expected. In addition, because those in the treatment group have a relationship with the mentor, they ought to also have been easier to contact in the follow-up surveys leading to a higher response rate relative to those in the control group. At the end of the results section, we discuss the consequences of differential attrition and non-response. ${ }^{15}$

The only available measure of program participation is the stipend or accrual accounts participants received. This is problematic as mentoring time did not count toward stipends or accrual account contributions. In addition, enrollees received "bonus hours" when they achieved a significant milestone, such as obtaining a B average or higher on his or her report card. These bonus hours cannot be distinguished from regular hours. Their inclusion overestimates time spent on program activities for some enrollees.

\footnotetext{
${ }^{15}$ We were also able to use transcripts data and exploit the fact that survey non-respondents did not necessarily overlap across surveys to build two variables measuring high-school completion and GED diploma receipt for most of the population at each point in time. We recoded as high-school graduates those survey non-respondents who had reported in an earlier survey being a high school graduate or for whom their transcript data clearly confirmed that they had indeed graduated from high-school. Similarly, we recoded as high-school dropouts those first- (or second-) survey non-respondents who had later responded to the second or third surveys and who had reported having dropped out of high-school. In addition, in the few cases where we found inconsistencies across surveys or across survey and transcripts, we used the answer that was corroborated at least twice. Several robustness checks have been performed using alternative definitions of high-school graduation and the results are robust to those reported in the main tables. For these two variables, differences in the response rates are considerably smaller (although they remain statistically significant at the 5 percent level as shown in Table 2).
} 


\section{E. Implementation of QOP and Service Use}

Overall, QOP was successfully implemented. Most case managers reported developing close mentoring relationships with the majority of the individuals assigned to them, and they all provided access to services regardless of enrollees' behavior. ${ }^{16}$

Although the educational, community service and development activity component fell short of the target of 750 hours per year, enrollees still invested a substantial amount of time in QOP activities during the first four years. The average of 886 hours, including summers but not time spent with their mentors, corresponds to about 89 percent of an extra school year and more than half the average instruction time received by Job Corps participants, by far the most intensive education and training program for disadvantaged youths in the United States (Schochet et al., 2008). The fact that QOP did not achieve its extremely ambitious target should not affect the external validity of this evaluation; if the program were implemented on a broader scale, it is likely that its implementation would be similar.

Enrollees spent an average of 61 hours per year on education, 76 hours on developmental activities, and 27 hours in community service. ${ }^{17}$ Not surprisingly, the average time spent on QOP activities fell steadily from 279 hours in the first year of the experiment to 125 hours in the fourth year (see Appendix Table A.3). Youths who had participated in QOP activities early during the experiment and then stopped or decreased participation over time gave leaving school, working, and family responsibilities as the main reasons for doing so. It is important to highlight, however, that almost the totality of QOP youths engaged in QOP activities, as all but 1 percent of enrollees spent some time on QOP activities in the first year.

Appendix Table A.3 also shows the distribution of hours over activities and year by whether youths were in the bottom- or top-half of the predicted drug use distribution. It is important to highlight that youths in the top-half of the risk distribution spent

\footnotetext{
${ }^{16}$ See Maxfield et al. 2003a, and Maxfield et al., 2003b, for further description of program design and implementation.

${ }^{17}$ In the case of community services, the lower intake was due to enrollees' lack of interest in this type of activities and case managers' belief that enrollees had a greater need for other QOP services. Most sites decided to reallocate their resources away from community service to developmental and educational activities.
} 
slightly more hours in QOP activities than those in the bottom-half (albeit the difference is not statistically significant). In addition, although youths in the top-half of the risk distribution spent less hours during the first year than those in the bottomhalf, the opposite is true during the fourth year, suggesting a more persistent involvement with QOP. Indeed we observe that while a higher percentage of them (44 percent) were no longer involved in QOP during the fourth year, of those who were still involved in QOP, the intensity of involvement was higher among those in the tophalf of the risk distribution.

\section{Results}

\section{A. Results}

Tables 3 through 6 display results for the summary indices followed by each specific outcome that were components of the index. Each table covers each of the key domains under analysis, high-school, post-secondary education, labor market, and risky behaviors, measured in the short-, medium- and long-run. To draw general conclusions about the results of the experiment, we begin with the summary indices for a given category and then we discuss the individual outcomes as the magnitudes of these separate outcomes are often easier to interpret than those of the summary indices. Columns 1 to 3 present the control group outcome means for the whole sample and separately for those in the bottom- or top-half of the fitted distribution of drug use. Columns 4 presents ITT estimates of the QOP effect for the whole sample. Separate ITT estimates for those in the bottom- or top-half of the fitted distribution of drug use are displayed in columns 5 and 6. Our discussion focuses on the effects of QOP on those in the top- and bottom-half of the risk distribution. It is important to keep in mind that a positive coefficient on the summary indices indicates a beneficial effect of the program, and a negative coefficient indicates a detrimental effect of QOP.

Control Group Means. - Column 1 of Tables 3 though 6 display mean outcomes for the control group. When youths were in their late-teens, we observe that close to 44 percent of those in the control group had graduated from high-school, and an 
additional 7 percent had obtained a GED. At the same time, 27 percent of them were attending post-secondary education, and 19 percent were in college. In terms of risky behaviors, 19 percent reported binge drinking, 27 percent reported using illegal drugs in the past month, and a bit over one fourth reported committing a crime in the last year or ever being arrested. Three years later, when youths were in their earlytwenties, both the percent of those with a high-school degree or a GED had gone up to 57 and 13.5 percent, respectively, and as many as 55 percent of youths had been enrolled in post-secondary education (34 percent in college). In terms of their labor force involvement, 73 percent were working (57 percent in a full-time job), and their average hourly wage was \$7 US dollars per hour. With the exception of binge drinking, risky behaviors had decreased: 16 percent report using illegal drugs and 8 percent report committing a crime. When we last surveyed them, 5 to 6 years after scheduled high-school graduation, we observe that 62 percent had graduated from high-school, 17 percent obtained a GED, and 56 percent had been enrolled in postsecondary education at some point in time. These averages are not far from the national average of 67 percent for high-school degree, 12 percent for GED, and 58 percent for similarly disadvantaged youths (U.S. Department of Education 2002b), but they are low compared to the national averages for the whole population discussed in the introduction. In addition, about 38 percent of youths in the control group had attended college, 30 percent had completed 2 years of college, and 7 percent had obtained a bachelor's or associate degree. Most of them (70 percent) were working at the time of the interview and their yearly earnings were, on average, $\$ 13,470$ US dollars. With age, youths' drug use and crime continues to go down with 12 percent reporting having used drugs in the past month and 2 percent having reported committing a crime.

Columns 2 and 3 of Tables 3 though 6 display control means by whether youths in the control group were in the top- or bottom-half of the predicted drug use distribution. We observe that average drug use for youths in the top-half of the predicted drug use distribution doubles that of youths in the bottom-half. In addition, reported crime is also higher for the former than the latter. These results persist over time as youths age. Focusing now on high-school outcomes, we also observe that, 
when they were in their late teens, those in the top-half of the risk distribution are about 6 percentage points less likely to have graduated from high-school than those in the bottom-half. This differential persists and increases over time: when youths are in their mid-twenties, those in the top-half are 12 percentage points less likely to have graduated from high-school than those in the bottom-half. Similarly, we observe that youths in the top-half of the risk distribution are, on average, less likely to be employed and they earn on average lower earnings than those in the top-half. In contrast, we do not observe any differences in terms of math and reading test scores when youths were in their late-teens. Similarly, we do not observe any differences in terms of enrolling in college or post-secondary education.

High-School Outcomes. - Columns 5 and 6 of Table 3 bring to light a new result: QOP worked extremely well in terms of increasing high-school graduation for youths in the top-half of the predicted drug use distribution, and this result persist over time as youths age. Column 5 of Table 3 shows a zero ITT estimate of QOP on the highschool domain for youths with low-predicted drug use in the short-run that becomes negative although not statistically significant when youths are in their early- and latetwenties. In contrast, the ITT estimates of QOP for youths with high-predicted drug use during high-school show large, significant, and persistent ITT effects of QOP on the high-school domain. The estimates of 0.099, 0.101 and 0.085 in column 6 of Table 3 indicate that the mean effect of being in the treatment group for the highschool outcomes is one tenth to one thirteenth standard deviations for youths in the top-half of the predicted drug distribution. The individual outcomes reveal that these beneficial effects are driven by statistically significant increases in the incidence of graduating from high-school (by about 10 percentage points). As the high-school graduation rate in the control group among those in the top-half of the fitted distribution is 40 percent in the short-run, 51 percent in the medium-run and 55 percent in the long run, the treatment effect corresponds to a 24 percent increase when youths were in their late-teens, 20 percent increase when youths were in their earlytwenties, and 18 percent increase when youths were in their mid-twenties. Because the control group means of those in the top-half of the distribution are 6, 10 and 12 percentage points lower than those in the bottom-half, it appears that QOP reduced 
treated youths differences in terms of high-school graduation by increasing the performance of those with a high predicted risk of drug use while in school towards the level of those with a lower predicted risk.

College Outcomes. - Moving now to Table 4, we observe that the only statistically significant ITT estimate of the college domain is that of youths in the top-half of the risk distribution measured when youths were in their early-twenties (shown in column 6 of Table 4). For youths in the top-half of the risk distribution, the other estimates are not statistically significant although the size of the coefficients are quite large (and in the medium- and long-run double the estimates measured for youths in the bottom-half of the distribution). The individual outcomes reveals that the positive and statistically significant effect in the medium-run is driven by an 7.9 percentage points (or 24 percent) increase in the odds of attending college. This effect persist over time: by the time youths are in their mid-twenties, QOP increased the likelihood of ever attending college of those in the top-half of the risk distribution by 10.1 percentage points (or 28 percent). As there are few differences in the control group means between those in the bottom- and top-half of the risk distribution, QOP did not narrow the gap between the two groups in terms of post-secondary educational outcomes.

Employment Outcomes.-Information on employment was first collected at the time of the $2^{\text {nd }}$ survey, when youths were in their early twenties. For results measured at that time, we observe a negative and statistically significant effect at the 5 percent level effect for males with low-predicted chance of using drugs during high-school. The ITT estimates of -0.205 in column 5 of Table 5 indicates that the mean effect of being in the treatment group for the six employment outcomes is one fifth of a standard deviation for those with low-predicted probability of using drugs. The individual estimates show that these treated youths were 11.5 percentage points less likely to have a job than youths in the control group, and that they worked on average about 5 less hours per week than youths in the control group. These effects are significant at the 5 percent level. These negative effects on employment may be explained by the fact that treated youths are more likely to be enrolled in postsecondary education (although effects on post-secondary attendance for this group are 
not statistically significant as shown in column 5 of Table 4). It is also interesting to note that we do not observe negative effects on employment when youths were in their early twenties for those in the top-half of the risk distribution despite finding that QOP increased both their post-secondary education and college enrollment. By the time youths are in their mid-twenties, the negative ITT effect on the employment domain of youths in the bottom-half of the risk distribution is considerably smaller and no longer significant.

Risky-Behavioral Outcomes.- QOP managed to curb risky behaviors among those most at-risk at least while the program was operating. When youths were in their lateteens, the ITT estimate for the summary index in column 6 of Table 6 indicate a positive effect of 0.102 (significant at the 90 percent level) for youths in the top-half of the risk distribution. The individual variables indicate that QOP's positive effect on reducing risky behaviors for this group is driven by all of the individual estimates, albeit being measured with less precision. In contrast, the effect is -0.162 for those with low-predicted risk of drug use (significant at the 99 percent level) reveals that QOP increased risky behaviors among this group during their late-teens. This is driven by an increase in the likelihood of binge drinking, using drugs in the past month, and committing in crime in the past year of 12.2, 16.5, and 9.5 percentage points, respectively. As the control group means of those in the bottom-half of the predicted drug use distribution are 6 to 20 percentage points lower than those in the top-half, it appears that QOP again narrowed the gap between the two groups.

Over time, QOP's positive effects on reducing risky behaviors fade away. By the time youths were in their early-twenties, the ITT estimates for the risky behaviors domain are considerably smaller and no longer statistically significant. The only beneficial effect of QOP that remains is that the program continued to be effective at reducing drug use for youth with a high-risk of drug use. QOP decreased drug use among this group by 8.4 percentage points (or 40 percent)--statistically significant at the 95 percent level. It is important to note, though, that engagement in risky behaviors decreases as youths age and is at its peak when youths are in their late-teens. Thus, the fading positive effect of QOP on risky behaviors when youths are in their 
twenties does not necessarily imply that QOP failed in its objective of reducing risky behaviors among youths in the top-half of the risk distribution.

QOP's negative effect on risky behaviors for youths in the bottom-half of the risk distribution also fades away when youths are in their early-twenties. At that point in time, the ITT estimate is close to zero and not statistically significant. In addition, the coefficients for the individual estimates are also close to zero (not significant) and sometimes negative (implying a reduction instead of an increase in substance abuse).

By the time youths are in the their mid-twenties, we observe a negative and significant effect of QOP on the risky behaviors' domain among youths in the bottomhalf of the risk distribution. This effect is driven by a 5.4 percentage points higher likelihood of arrests (significant at the 5 percent level). For youths in the top-half of the risk distribution, we also observe a negative (albeit non significant) effect of QOP. This is not the only intervention to find unanticipated adverse effect on crime in the long-run. Kling et al., 2005 also find that the Moving to Opportunity (MTO) housing vouchers led to short-term reductions in violent crime arrests, but long-term increases in property crime arrests for males. Similarly, the randomized, experimental trial of the community-based treatment program Cambridge-Somerville Youth Study, whose objective was to prevent delinquency, found that youths in the treatment group were more likely in the long run to be rearrested for crimes and have further negative impacts on physical and psychological health compared to youths in the control group (McCord, 1978 and 1992). The impacts were measured up to 30 years later using official state records.

Potential Mechanisms. - Unfortunately, the evaluation of QOP was not designed to test alternative mechanisms. However, the analysis thus far reveals that QOP worked very well for youths with a high-predicted risk of drug use as it decreased their engagement in risky behaviors during high-school, and increased high-school graduation rate, and post-secondary educational involvement. Most importantly, the educational beneficial results persisted over time. Thus, it appears that QOP's mentors, who were social workers, did a good job at identifying youths most at-risk 
and addressing their non-cognitive and structural barriers, and by doing so their educational outcomes improved. To corroborate this, we find evidence that treated youths in the top-half of the distribution became more optimistic about life at the end of the program than those in the control group. For instance, they were 6.5 percentage points (or 8 percent) more likely to believe that life will be happy, or 5.1 percentage points (or 6 percent) more likely to agree that they would not die before 30. Both estimates are statistically significant at the 90 percent level. In contrast, for those in the bottom-half of the distribution, QOP did not have any positive effect on their outlook of life. ${ }^{18}$

In contrast, QOP did not seem to work that well among treated youths in the bottomhalf of the distribution as it had no effect on educational outcomes, and it increased engagement in risky behaviors while in high-school. So, what went wrong during implementation for youths with low-predicted chance of problem behavior? Negative peer effects are a plausible explanation. As discussed earlier, each mentor in QOP had assigned several mentees with whom he or she frequently worked at the same time as a group. In addition QOP offered cultural and recreational activities to treated youths to help them build strong relationships with mentors and peers. However, building strong cohesion within a group may have backfired. Evidence from psychologists and economists reveals that peer effects play an important role on getting youths involved in risky activities. This occurs because peers reinforce deviant conduct by responding with approval and attention (Dishion, et al., 1999; Dishion, et al., 1996; and Patterson, et al., 2000). ${ }^{19}$

To test whether negative peer effects is a plausible story, we estimated the following peer effects variable. For each individual we estimated the proportion of students within the same school, treatment status, sex, and race, that reported doing drugs at

\footnotetext{
${ }^{18}$ Control means for the control group in the top-half of the risk distribution are 80 percent for agreeing that life will be happy and 88 percent for agreeing that they will not die before 30 . For those in the bottom half of the risk distribution, control group means are 79 percent and 91 percent.

${ }^{19}$ See Brook et al., 1998; Kandel, 1985; Jessor et al., 1980 for peers' influence on marijuana use; Norton et al., 1998, Jensen and Lleras-Muney, 2010 for drinking and peer effects; and Case and Katz, 1991 for peer-group interactions and criminal activity.
} 
age 19. We then re-estimated equation (1) including this peer effect variable and its interaction with QOP. If the story is negative peer effects we would expect a negative and significant coefficient on this interaction term. Table 7 displays these estimates. Among youths in the bottom-half of the risk distribution, we observe that there is a negative peer effect for youths in the treatment group. For instance, the coefficient on the interaction between being treated and the peer variable is negative and statistically significant for the college outcome both in the short- and medium-run, and the highschool outcome in the short-run, indicating that having peers who engaged in drug use during high-school decreased the beneficial effect of QOP in this domain both in the short- and medium-run. Once we account for this peer effect, QOP improves the college outcomes in the short-run and medium-run for youths in the bottom-half of the distribution. Similarly, the estimate of QOP on risky behaviors when youths were in their late-teens, becomes positive, and the interaction between QOP and the peers effect variable is negative. Although these coefficients are estimated with less precision, this sign reversal on the treatment dummy suggests that negative peer effects among treated youths in the bottom-half of the distribution are a part of the story behind these treated youths' increased engagement in risky behaviors during high-school.

Finally, could negative peer effects explain the long-run detrimental effects of QOP on risky behaviors found earlier by Rodríguez-Planas (forthcoming AEJ: Applied Economics)? When looking at the whole sample, we observe that introducing our measure of peer effects based on drug use at age 19 has a negative and statistically significant impact on engagement in risky behaviors among treated youths when these were in their early- and mid-twenties. In addition, the coefficient on the treatment dummy becomes positive and significant in the medium-run and positive (albeit not significant) in the long-run. Table 7 also shows that these negative peer effects on risky behaviors are particularly large among youths in the top-half of the risk distribution. Thus, it seems that while mentors were able to curb risky behaviors among those at high-risk during high school, they did not succeed in changing behavior in the long run. Notice that while there are potentially alternative and 
complementary explanations for this result, one would still need to explained why they were driven by those who had a higher percentage of peers during high-school doing drugs. The bottom line is that the evidence in Table 7 is suggestive that negative peer effects may well be behind QOP's detrimental long-run effect on risky behaviors.

\section{B. Robustness Section}

Clustering Standard Errors at the School Level.- Appendix Table A.4 presents estimates for each of the four domains clustering the standard errors at the school level, which was the unit of randomization. When doing so standard errors are usually a bit smaller and thus it increases the precision of our estimates. Clustering standard errors at the school-level does not affect the main results presented thus far.

Attrition from the Follow-up Surveys.-As we saw in the data section, differential attrition between treated and control groups exists especially among youths in the tophalf of the predicted drug use distribution. Here, we analyze the sensitivity of the estimates to potential attrition bias. First, we set the response rate for the QOP group equal to the response rate for the control group within each of the 11 QOP schools and by whether youths were in the top- or bottom-half of the risk distribution. That is, we eliminated the last (and thus the most difficult to find) treatment group respondents until the "response rates" of the control and treatment groups were equalized at the school and top- (or bottom)-half of the risk distribution. The estimates obtained in this way (see Appendix Table A.5) are similar to those presented earlier, suggesting that higher response rates among the treatment group youths are not driving the results.

In addition, since we were able to construct high-school completion and GED diploma receipt for a considerably more complete sample using transcript data (as explained in footnote 15 in Section I.D and shown in Table 2), we compare these estimates of QOP (discussed in the main text and shown in Table 3) to those estimated using the attrited sample. Appendix Table A.6 displays these results, and shows that differences across the two estimates are small. 


\section{Conclusion}

Rodríguez-Planas (forthcoming AEJ: Applied Economics) estimates average effects of QOP and finds that although the program was successful in the short-term, in the long-run its educational results were modest and its effects on risky behaviors detrimental. As a consequence, many question whether the outcomes of the program warrant its intensity and high costs. This paper takes a different approach and finds that QOP worked extremely well among youths with a high-predicted risk of drug use. By doing so, we unveil how QOP may have worked: it managed to curb risky behaviors among those most at risk during high-school and thus, it improved their educational outcomes both in the short-, medium-, and long-run. In contrast, we find suggestive evidence that QOP was unsuccessful among youths in the bottom-half of the distribution because it increased their engagement in risky behaviors while in highschool. The evidence presented seems to suggest that negative peer effects may explain this. Perhaps more importantly, we also find evidence suggesting that negative peer effects may also be behind the puzzling negative effects of QOP on long-run risky behavioral outcomes.

While we explored alternative explanations for these results, the evidence we found was weaker. For instance, an alternative explanation is that because QOP gave stipends, youths may have used this additional income to purchase alcohol and drugs. $^{20}$ However, on average treated youths got \$350 the first year and \$156 the fourth year. Per week, this represents $\$ 6$ and less than $\$ 3$ in the first and fourth year, respectively. While $\$ 1.25$ per hour may have encouraged participation, overall youths got much less than minimum wage, which went from \$4.25 in 1995 to \$5.15 in 1999 . Thus, it is unlikely that QOP's stipends alone would explain the observed substance abuse. Another explanation is that QOP may have led to a substitution away from parents' attention, either because they trusted that the mentor was also watching over their children, or because QOP unintentionally weakened the ties between parents and enrollees, breaking important social bonds and thus leading to the observed perverse

\footnotetext{
${ }^{20}$ There is growing evidence showing that youths are very responsive to economic incentives, such as prices, when deciding to undertake risky behaviors (Nisbet and Vakil, 1972; Grossman et al., 1994; Chaplouka and Wechler, 1996; Gruber, 2001; Pacula et al., 2001).
} 
effects. And that this happened mainly among youths in the bottom-half of the risk distribution (as those in the top-half did not have those strong family ties to start with). To explore whether this could be a possible explanation we re-estimated equation (1) adding a dummy equal to 1 if the youth reported having an influential adult during high-school and the interaction of this variable with the treatment effect. ${ }^{21}$ If the negative effect on risky behaviors for youths in the bottom-half of the distribution were caused by a substitution effect, we would find that this detrimental effect of QOP on risky behaviors would be partly explained by this interaction. We found no evidence of that. In the contrary, estimates suggests that, if anything, mentors decreased youths' engagement in risky behaviors. ${ }^{22}$

\section{REFERENCES}

Angrist, Joshua D., and Victor Lavy. 2009. “The Effect of High School Matriculation Awards: Evidence from Randomized Trials.” American Economic Review, 99 (4): 1384-1414.

Carneiro, P., and J. Heckman, James J., 2003. "Human Capital Policy," IZA Discussion Papers 821, Institute for the Study of Labor (IZA).

Cook, Phillip J., and Michael J. Moore. “Alcohol.” In Handbook of health economics, vol. 1b, ed. Anthony Culyer and Joseph Newhouse, 629-74. Amsterdam: Elsevier.

Currie, Janet. 2001. "Early childhood education programs.” Journal of Economic Perspectives 15, no. 2:213-38.

de Walque, Damien (2007). "Does Education Affect Smoking Behaviors?: Evidence

Using the Vietnam Draft as an Instrument for College Education," Journal of Health Economics, 26(5), p. 877-895.

\footnotetext{
${ }^{21}$ Clearly including having a dummy indicating presence of an influential adult while in high-school is endogenous, however, we do this only to see how much of the estimated causal detrimental effect of QOP could be driven by an influential adult substituting parents' attention. We find that if anything mentors decreased youths' engagement in risky behaviors.

${ }^{22}$ The coefficient on the QOP dummy in the risky behaviors domain becomes -0.272 (s.e. 0.110 ) and the interaction between QOP and having an influential adult is 0.163 (s.e. 0.129) for youths in the bottom-half of the distribution. Similarly, for youths in the top-half of the distribution, the coefficient on the QOP dummy becomes 0.015 (s.e. 0.122) and the interaction term becomes $0.142(0.143)$.
} 
Duckworth, Angela, and Martin Seligman. 2006. "Self-Discipline Gives Girls the Edge: Gender in Self-Discipline, Grades, and Achievement Test Scores.” Journal of Educational Psychology 98(1): 198-208.

Dynarski, Susan. 2003. "Does Aid Matter? Measuring the Effect of Student Aid on College Attendance and Completion.” American Economic Review 93(1): 279-88.

Dynarski, Susan. 2008. "Building the Stock of College-Educated Labor." Journal of Human Resources, 43(3): 576-610.

Grant JE, Potenza MN, Krishnan-Sarin S, 2011. "Stealing among high school students: prevalence and clinical correlates." J Am Acad Psychiatry Law 39:44-52.

Gutman LM, Sameroff AJ, Eccles JS. 2002. "The academic achievement of African American students during early adolescence: an examination of multiple risk, promotive, and protective factors." Am. J. Community Psychol. 30:367-99

Grimard, Franque \& Parent, Daniel, 2007. "Education and smoking: Were Vietnam war draft avoiders also more likely to avoid smoking?," Journal of Health Economics, Elsevier, vol. 26(5), pages 896-926, September.

Heckman, James J., 2000. "Policies to foster human capital," Research in Economics, Elsevier, vol. 54(1), pages 3-56, March.

Jensen R., and A. Lleras-Muney. Does Staying in School (and not Working) prevent Teen Drinking and Smoking? Forthcoming. Journal of Health Economics.

Kenkel, D. S. 1993. "Drinking, driving, and deterrence: The effectiveness and social costs of alternative policies." Journal of Law and Economics 36:877-913.

Kling, Jeffrey R., Jeffrey B. Liebman, and Lawrence F. Katz. 2005. "Neighborhood Effects on Crime for Female and Male Youth: Evidence from a Randomized Housing Voucher Experiment.” Quarterly Journal of Economics, 120(1):87-130, 2005.

Kling, Jeffrey R., Jeffrey B. Liebman, and Lawrence F. Katz. 2007. “Experimental Analysis of Neighborhood Effects.” Econometrica, 75 (1): 83-119.

Krueger A., and D. Whitmore, 2001. "Would Smaller Classes Help Close the BlackWhite Achievement Gap?," Working Papers 830, Princeton University, Department of Economics, Industrial Relations Section..

Lavy, Victor, and Analia Schlosser. 2005. "Targeted Remedial Education for Underperforming Teenagers: Costs and Benefits.” Journal of Labor Economics, 23(4): 839-74. 
Machin, Steven, Sandra McNally, and Costas Meghir, 2004. "Improving Pupil Performance in English Secondary Schools: Excellence in Cities," Journal of the European Economic Association, MIT Press, vol. 2(2-3), pages 396-405, 04/05.

Maxfield, Myles, Laura Castner, Vida Maralani, and Mary Vencill. 2003. "The

Quantum Opportunity Program Demonstration: Implementation Findings.”

Washington, DC: Mathematica Policy Research, Inc.

Maxfield, Myles, Allen Schirm, and Núria Rodríguez-Planas. 2003. “The Quantum Opportunities Program Demonstration: Implementation and Short-Term Impacts.” Mathematica Policy Research Report 8279-093. Washington, DC: Mathematica Policy Research, Inc.

McCord, Joan. 1978. “A thirty-year follow-up of treatment effects.” American Psychologist, 2, 284-289.

McCord, Joan. 1992. "The Cambridge-Somerville Study: A pioneering longitudinalexperimental study of delinquency prevention.” In J. McCord \& R. E. Tremblay (Eds.), Preventing antisocial behavior: Interventions from birth through adolescence (pp. 196-206). New York: Guilford Press.

OECD, 2009. “Comparative Child Well-being across the OECD.” Chapter 2 in Doing Better for Children, OECD.

OECD, 2011 Educaiton in figures.

Rodríguez-Planas, N. "Longer-Term Impacts of Mentoring, Educational Services, and Learning Incentives: Evidence from a Randomized Trial in the U.S.” American Economic Journal: Applied Economics (forthcoming October 2012).

Rodríguez-Planas, N. “Mentoring, Educational Services, and Financial Incentives: What Do We Know about Them?” Evaluation and Program Planning, 2012, 35, 481-490.

Sander, William. (1995a). "Schooling and Quitting Smoking," Review of Economics and Statistics, 77, p. 191-199.

Sander, William. (1995b). "Schooling and Smoking," Economics of Education Review, 14, p. 23-33.

Schochet, Peter, John Burghardt, and Sheena McConnell. 2008. "Does Job Corps Work? Impact Findings from the National Job Corps Study.” American Economic Review, 98:5, 1864-1886. 
Silverman, Irwin. 2003. “Gender Differences in the Delay of Gratification: A MetaAnalysis.” Sex Roles, 49(9-10): 451-463.

Steinberg, L. 2004. "Risk taking in adolescence: What changes, and why?" Annals of the NewYork Academy of Sciences, 1021, 51-58.

U.S. Department of Education, National Center for Education Statistics. The Condition of Education 2005. NCES 2005-094. Washington, DC: U.S. Department of Education.

Warner, John, and Saul Pleeter. 2001. “The Personal Discount Rate: Evidence from Military Downsizing Programs.” The American Economic Review, 91(1): 33-53.

Yamada, Tetsuji, Michael Kendix, and Tadashi Yamada. 1996. The impact of alcohol consumption and marijuana use on high school graduation. Health Economics 5, no. 1:77-92. 
TABLE 1. Descriptive Statistics By Predicted Drug Use at Age 19

\begin{tabular}{|c|c|c|c|c|c|c|c|c|c|}
\hline & & & & \multicolumn{3}{|c|}{ Low-risk of drug use at 19} & \multicolumn{3}{|c|}{ High-risk of drug use at 19} \\
\hline & $\begin{array}{l}\text { Treatment } \\
\text { means }\end{array}$ & $\begin{array}{l}\text { Control } \\
\text { means }\end{array}$ & $\begin{array}{l}\text { Treatment } \\
\text { - Control }\end{array}$ & $\begin{array}{c}\text { Treatment } \\
\text { means }\end{array}$ & $\begin{array}{c}\text { Control } \\
\text { means }\end{array}$ & $\begin{array}{l}\text { Treatment } \\
\text { - Control }\end{array}$ & $\begin{array}{c}\text { Treatment } \\
\text { means }\end{array}$ & $\begin{array}{c}\text { Control } \\
\text { means }\end{array}$ & $\begin{array}{l}\text { Treatment } \\
\text { - Control }\end{array}$ \\
\hline & $(1)$ & $(2)$ & $(3)$ & $(4)$ & $(5)$ & $(6)$ & $(7)$ & $(8)$ & (9) \\
\hline \multicolumn{10}{|l|}{ Baseline Covariates } \\
\hline Male & 0.522 & 0.558 & $\begin{array}{c}-0.040 \\
(0.030)\end{array}$ & 0.502 & 0.587 & $\begin{array}{c}-0.078 * * \\
(0.039)\end{array}$ & 0.544 & 0.526 & $\begin{array}{l}-0.016 \\
(0.038)\end{array}$ \\
\hline \multicolumn{10}{|c|}{ Age when entering $9^{\text {th }}$ grade } \\
\hline$<14$ & 0.107 & 0.110 & $\begin{array}{c}-0.000 \\
(0.019)\end{array}$ & 0.084 & 0.101 & $\begin{array}{c}-0.022 \\
(0.024)\end{array}$ & 0.132 & 0.121 & $\begin{array}{c}0.018 \\
(0.028)\end{array}$ \\
\hline 14 & 0.533 & 0.575 & $\begin{array}{l}-0.040 \\
(0.030)\end{array}$ & 0.552 & 0.568 & $\begin{array}{c}0.007 \\
(0.039)\end{array}$ & 0.512 & 0.582 & $\begin{array}{l}-0.069 \\
(0.043)\end{array}$ \\
\hline$>14$ & 0.360 & 0.315 & $\begin{array}{c}0.041 \\
(0.028)\end{array}$ & 0.364 & 0.331 & $\begin{array}{c}0.015 \\
(0.039)\end{array}$ & 0.356 & 0.297 & $\begin{array}{c}0.050 \\
(0.040)\end{array}$ \\
\hline Hispanic & 0.262 & 0.257 & $\begin{array}{c}0.005 \\
(0.016)\end{array}$ & 0.411 & 0.381 & $\begin{array}{c}0.023 \\
(0.022)\end{array}$ & 0.103 & 0.121 & $\begin{array}{c}0.001 \\
(0.018)\end{array}$ \\
\hline Black & 0.683 & 0.679 & $\begin{array}{c}0.004 \\
(0.013)\end{array}$ & 0.555 & 0.564 & $\begin{array}{l}-0.003 \\
(0.014)\end{array}$ & 0.818 & 0.806 & $\begin{array}{c}0.001 \\
(0.019)\end{array}$ \\
\hline \multicolumn{10}{|c|}{ Rank based on $8^{\text {th }}$ grade GPA } \\
\hline Bottom third & 0.365 & 0.329 & $\begin{array}{c}0.037 \\
(0.029)\end{array}$ & 0.415 & 0.361 & $\begin{array}{c}0.048 \\
(0.041)\end{array}$ & 0.313 & 0.293 & $\begin{array}{c}0.015 \\
(0.041)\end{array}$ \\
\hline Middle third & 0.307 & 0.352 & $\begin{array}{c}-0.044 \\
(0.029)\end{array}$ & 0.224 & 0.288 & $\begin{array}{c}-0.067^{*} \\
(0.037)\end{array}$ & 0.395 & 0.422 & $\begin{array}{l}-0.018 \\
(0.043)\end{array}$ \\
\hline Top third & 0.328 & 0.319 & $\begin{array}{c}0.008 \\
(0.029) \\
\end{array}$ & 0.361 & 0.350 & $\begin{array}{c}0.019 \\
(0.041) \\
\end{array}$ & 0.292 & 0.284 & $\begin{array}{c}0.003 \\
(0.040) \\
\end{array}$ \\
\hline \multicolumn{10}{|l|}{ Additional Variables } \\
\hline Peers' drug use at 19 & $\begin{array}{c}28.505 \\
(13.158)\end{array}$ & $\begin{array}{c}21.063 \\
(13.581)\end{array}$ & $\begin{array}{l}0.071^{* * *} \\
(0.008)\end{array}$ & $\begin{array}{c}26.916 \\
(12.912)\end{array}$ & $\begin{array}{l}15.554 \\
(9.557)\end{array}$ & $\begin{array}{c}0.112^{* * *} \\
(0.009)\end{array}$ & $\begin{array}{c}30.194 \\
(13.230)\end{array}$ & $\begin{array}{c}27.166 \\
(14.739)\end{array}$ & $\begin{array}{l}0.025^{* *} \\
(0.012)\end{array}$ \\
\hline Predicted drug use at 19 & 0.272 & 0.274 & $\begin{array}{c}-0.011 \\
(0.007)\end{array}$ & 0.175 & 0.190 & $\begin{array}{c}-0.017^{* *} \\
(0.007)\end{array}$ & 0.375 & 0.368 & $\begin{array}{c}0.004 \\
(0.010)\end{array}$ \\
\hline Sample size & 580 & 489 & 1,069 & 299 & 257 & 556 & 281 & 232 & 513 \\
\hline
\end{tabular}


TABLE 2. Treatment Effect on Response Rates By Predicted Drug Use at Age 19

\begin{tabular}{|c|c|c|c|c|c|c|c|c|c|}
\hline & & & & \multicolumn{3}{|c|}{ Low-risk of drug use at 19} & \multicolumn{3}{|c|}{ High-risk of drug use at 19} \\
\hline & \multirow[t]{2}{*}{$\begin{array}{c}\text { Control } \\
\text { means }\end{array}$} & \multicolumn{2}{|c|}{ Treatment - Control } & \multirow[t]{2}{*}{$\begin{array}{c}\text { CONTROL } \\
\text { MEANS }\end{array}$} & \multicolumn{2}{|c|}{ TREATMENT-CONTROL } & \multirow[t]{2}{*}{$\begin{array}{c}\text { CONTROL } \\
\text { MEANS }\end{array}$} & \multicolumn{2}{|c|}{ TREATMENT-CONTROL } \\
\hline OUTCOMES & & $\begin{array}{c}\text { School } \\
\text { dummies }\end{array}$ & $\begin{array}{c}\text { Full set of } \\
\text { controls }\end{array}$ & & $\begin{array}{c}\text { School } \\
\text { dummies }\end{array}$ & $\begin{array}{c}\text { Full set of } \\
\text { controls }\end{array}$ & & $\begin{array}{c}\text { School } \\
\text { dummies }\end{array}$ & $\begin{array}{c}\text { Full set of } \\
\text { controls }\end{array}$ \\
\hline Achievement tests & 0.800 & $\begin{array}{c}0.080 * * * \\
(0.023)\end{array}$ & $\begin{array}{c}0.081 * * * \\
(0.022)\end{array}$ & 0.809 & $\begin{array}{c}0.055^{*} \\
(0.032)\end{array}$ & $\begin{array}{c}0.0512 \\
(0.0317)\end{array}$ & 0.789 & $\begin{array}{c}0.112 * * * \\
(0.0322)\end{array}$ & $\begin{array}{c}0.113 * * * \\
(0.0317)\end{array}$ \\
\hline First telephone survey & 0.795 & $\begin{array}{c}0.071^{* * *} \\
(0.023)\end{array}$ & $\begin{array}{c}0.072 * * * \\
(0.023)\end{array}$ & 0.817 & $\begin{array}{c}0.028 \\
(0.032)\end{array}$ & $\begin{array}{c}0.0263 \\
(0.0328)\end{array}$ & 0.772 & $\begin{array}{c}0.117^{* * *} \\
(0.0328)\end{array}$ & $\begin{array}{c}0.119 * * * \\
(0.0329)\end{array}$ \\
\hline Second telephone survey & 0.685 & $\begin{array}{c}0.096 * * * \\
(0.027)\end{array}$ & $\begin{array}{c}0.097 * * * \\
(0.0273)\end{array}$ & 0.689 & $\begin{array}{c}0.054 \\
(0.039)\end{array}$ & $\begin{array}{c}0.051 \\
(0.039)\end{array}$ & 0.681 & $\begin{array}{c}0.146 * * * \\
(0.038)\end{array}$ & $\begin{array}{c}0.148 * * * \\
(0.038)\end{array}$ \\
\hline Third telephone survey & 0.724 & $\begin{array}{c}0.032 \\
(0.027) \\
\end{array}$ & $\begin{array}{c}0.0326 \\
(0.0270)\end{array}$ & 0.755 & $\begin{array}{l}-0.010 \\
(0.067)\end{array}$ & $\begin{array}{l}-0.013 \\
(0.037)\end{array}$ & 0.690 & $\begin{array}{c}0.081^{* *} \\
(0.040)\end{array}$ & $\begin{array}{c}0.083^{* *} \\
(0.040)\end{array}$ \\
\hline \multicolumn{10}{|c|}{ High-school and GED recodes } \\
\hline First survey & 0.926 & $\begin{array}{c}0.031 * * \\
(0.015)\end{array}$ & $\begin{array}{c}0.032 * * \\
(0.015)\end{array}$ & 0.934 & $\begin{array}{c}0.010 \\
(0.021)\end{array}$ & $\begin{array}{c}0.010 \\
(0.021)\end{array}$ & 0.918 & $\begin{array}{c}0.053 * * \\
(0.021)\end{array}$ & $\begin{array}{c}0.054 * * * \\
(0.021)\end{array}$ \\
\hline Second survey & 0.856 & $\begin{array}{c}0.046^{* *} \\
(0.020)\end{array}$ & $\begin{array}{c}0.049 * * \\
(0.020)\end{array}$ & 0.872 & $\begin{array}{c}0.004 \\
(0.029)\end{array}$ & $\begin{array}{c}0.008 \\
(0.029)\end{array}$ & 0.841 & $\begin{array}{c}0.094 * * * \\
(0.028)\end{array}$ & $\begin{array}{c}0.099 * * * \\
(0.028)\end{array}$ \\
\hline Third survey & 0.836 & $\begin{array}{c}0.046^{* *} \\
(0.021)\end{array}$ & $\begin{array}{c}0.050 * * \\
(0.021)\end{array}$ & 0.868 & $\begin{array}{l}-0.007 \\
(0.029)\end{array}$ & $\begin{array}{l}-0.005 \\
(0.029)\end{array}$ & 0.802 & $\begin{array}{c}0.107^{* * *} \\
(0.031)\end{array}$ & $\begin{array}{c}0.113^{* * *} \\
(0.031)\end{array}$ \\
\hline
\end{tabular}

Notes: Robust standard errors are reported in parentheses. "Full set of controls" includes school dummies, an indicator for being male, an indicator for being 14 years old when entering ninth grade, an indicator for being over age 14 when entering ninth grade, an indicator for being in the middle third of the eighth-grade GPA distribution, an indicator for being in the top third of the eight-grade GPA distribution, an indicator for being black and an indicator for being Hispanic.

$* *, * * *$ Estimate significantly different from zero at the $95 \%$, or $99 \%$ confidence level. 
TABLE 3. Treatment EfFect on High-School Outcomes By Predicted Drug Use at Age 19

\begin{tabular}{|c|c|c|c|c|c|c|}
\hline & \multicolumn{3}{|c|}{ CONTROL MEANS } & \multicolumn{3}{|c|}{ TREATMENT-CONTROL } \\
\hline & Full sample & Low-risk & High-risk & Full sample & Low-risk & High-risk \\
\hline OUTCOMES & & & & $\begin{array}{l}\text { Full set of } \\
\text { controls }\end{array}$ & $\begin{array}{l}\text { Full set of } \\
\text { controls }\end{array}$ & $\begin{array}{l}\text { Full set of } \\
\text { controls }\end{array}$ \\
\hline & (1) & $(2)$ & (3) & $(4)$ & (5) & $(6)$ \\
\hline \multicolumn{7}{|c|}{ Youths Were in their Late Teens } \\
\hline Summary measure & & & & $\begin{array}{l}0.056^{*} \\
(0.034)\end{array}$ & $\begin{array}{l}0.0031 \\
(0.049)\end{array}$ & $\begin{array}{l}0.099 * * \\
(0.047)\end{array}$ \\
\hline $\begin{array}{l}\text { Obtained high-school } \\
\text { Diploma }\end{array}$ & 0.435 & 0.463 & 0.404 & $\begin{array}{l}0.053^{*} \\
(0.029)\end{array}$ & $\begin{array}{c}0.007 \\
(0.041)\end{array}$ & $\begin{array}{l}0.095 * * \\
(0.041)\end{array}$ \\
\hline Obtained a GED & 0.076 & 0.061 & 0.093 & $\begin{array}{l}-0.009 \\
(0.017)\end{array}$ & $\begin{array}{l}-0.016 \\
(0.021)\end{array}$ & $\begin{array}{l}-0.001 \\
(0.028)\end{array}$ \\
\hline $\begin{array}{l}\text { Obtained HS diploma or } \\
\text { GED or still in HS }\end{array}$ & 0.636 & 0.662 & 0.606 & $\begin{array}{c}0.043 \\
(0.028)\end{array}$ & $\begin{array}{l}-0.022 \\
(0.039)\end{array}$ & $\begin{array}{l}0.098 * * \\
(0.041)\end{array}$ \\
\hline $\begin{array}{l}\text { Math test scores } \\
\text { (percentile) }\end{array}$ & $\begin{array}{l}40.541 \\
{[7.718]}\end{array}$ & $\begin{array}{l}40.741 \\
{[7.968]}\end{array}$ & $\begin{array}{l}40.316 \\
{[6.199]}\end{array}$ & $\begin{array}{c}0.368 \\
(0.426)\end{array}$ & $\begin{array}{c}0.632 \\
(0.623)\end{array}$ & $\begin{array}{l}-0.038 \\
(0.557)\end{array}$ \\
\hline Reading test scores & 42.884 & 42.909 & 42.854 & 0.406 & 0.252 & 0.420 \\
\hline (percentile) & [7.540] & [7.849] & [7.196] & $(0.484)$ & $(0.692)$ & $(0.647)$ \\
\hline \multicolumn{7}{|c|}{ Youths Were in their Early Twenties } \\
\hline Summary measure & & & & $\begin{array}{c}0.044 \\
(0.032) \\
\end{array}$ & $\begin{array}{c}-0.021 \\
(0.043) \\
\end{array}$ & $\begin{array}{c}0.101^{* * \dagger}+ \\
(0.048) \\
\end{array}$ \\
\hline $\begin{array}{l}\text { Obtained high-school } \\
\text { Diploma }\end{array}$ & 0.568 & 0.616 & 0.513 & $\begin{array}{c}0.032 \\
(0.030)\end{array}$ & $\begin{array}{l}-0.045 \\
(0.041)\end{array}$ & $\begin{array}{c}0.102 * * \dagger \dagger \\
(0.043)\end{array}$ \\
\hline Obtained a GED & 0.136 & 0.099 & 0.180 & $\begin{array}{c}0.008 \\
(0.023) \\
\end{array}$ & $\begin{array}{c}0.019 \\
(0.029) \\
\end{array}$ & $\begin{array}{c}-0.002 \\
(0.038) \\
\end{array}$ \\
\hline \multicolumn{7}{|c|}{ Youths Were in their Mid-Twenties } \\
\hline Summary measure & & & & $\begin{array}{c}0.024 \\
(0.030) \\
\end{array}$ & $\begin{array}{c}-0.038 \\
(0.042) \\
\end{array}$ & $\begin{array}{c}0.085^{*} \dagger \dagger \\
(0.044) \\
\end{array}$ \\
\hline $\begin{array}{l}\text { Obtained high-school } \\
\text { Diploma }\end{array}$ & 0.616 & 0.673 & 0.548 & $\begin{array}{c}0.021 \\
(0.030)\end{array}$ & $\begin{array}{l}-0.054 \\
(0.040)\end{array}$ & $\begin{array}{c}0.097 * * \dagger \dagger \\
(0.044)\end{array}$ \\
\hline Obtained a GED & 0.166 & 0.135 & 0.204 & $\begin{array}{c}0.002 \\
(0.024)\end{array}$ & $\begin{array}{c}0.012 \\
(0.031)\end{array}$ & $\begin{array}{c}-0.011 \\
(0.039)\end{array}$ \\
\hline
\end{tabular}

Notes: Standard deviation in brackets. The table reports estimates of treatment effects on the dependent variables indicated in row headings. Robust standard errors are reported in parentheses. "Full set of controls" includes school dummies, an indicator for being male, an indicator for being 14 years old when entering ninth grade, an indicator for being over age 14 when entering ninth grade, an indicator for being in the middle third of the eighth-grade GPA distribution, an indicator for being in the top third of the eight-grade GPA distribution, an indicator for being black and an indicator for being Hispanic.

$*, * *, * * *$ Estimate significantly different from zero at the $90 \%, 95 \%$ level, or 99\% level.

$\dagger, \uparrow+, \dagger \dagger$ indicates that the difference of the estimated effects between youths in the bottom- and top-half of the predicted drug use distribution is significant at the $90 \%$, $95 \%$, and $99 \%$ level. 
TABLE 4. Treatment Effect on Post-Secondary Education Outcomes By Predicted Drug Use at Age 19

\begin{tabular}{|c|c|c|c|c|c|c|}
\hline & \multicolumn{3}{|c|}{ CONTROL MEANS } & \multicolumn{3}{|c|}{ TREATMENT-CONTROL } \\
\hline & Full sample & Low-risk & High-risk & Full sample & Low-risk & High-risk \\
\hline OUTCOMES & & & & $\begin{array}{l}\text { Full set of } \\
\text { controls }\end{array}$ & $\begin{array}{c}\text { Full set of } \\
\text { controls }\end{array}$ & $\begin{array}{c}\text { Full set of } \\
\text { controls }\end{array}$ \\
\hline & $(1)$ & $(2)$ & (3) & (4) & (5) & (6) \\
\hline \multicolumn{7}{|c|}{ Youths Were in their Late Teens } \\
\hline Summary measure & & & & $\begin{aligned} 0.105^{*} \\
(0.059)\end{aligned}$ & $\begin{array}{c}0.094 \\
(0.082)\end{array}$ & $\begin{array}{r}0.129 \\
(0.084)\end{array}$ \\
\hline $\begin{array}{l}\text { Attending or accepted in } \\
\text { College }\end{array}$ & 0.268 & 0.268 & 0.268 & $\begin{array}{l}0.055^{*} \\
(0.029)\end{array}$ & $\begin{array}{c}0.024 \\
(0.040)\end{array}$ & $\begin{array}{c}0.087 * * \\
(0.042)\end{array}$ \\
\hline Attending college & 0.189 & 0.192 & 0.184 & $\begin{array}{c}0.030 \\
(0.026)\end{array}$ & $\begin{array}{c}0.031 \\
(0.036)\end{array}$ & $\begin{array}{c}0.036 \\
(0.037)\end{array}$ \\
\hline $\begin{array}{l}\text { Attending postsecondary } \\
\text { Education }\end{array}$ & 0.267 & 0.262 & 0.274 & $\begin{array}{c}0.050 \\
(0.030) \\
\end{array}$ & $\begin{array}{c}0.066 \\
(0.041) \\
\end{array}$ & $\begin{array}{c}0.044 \\
(0.044) \\
\end{array}$ \\
\hline \multicolumn{7}{|c|}{ Youths Were in their Early Twenties } \\
\hline Summary measure & & & & $\begin{array}{l}\text { 0.108* } \\
(0.060)\end{array}$ & $\begin{array}{c}0.061 \\
(0.082)\end{array}$ & $\begin{array}{l}0.177^{* *} \\
(\mathbf{0 . 0 8 3 )}\end{array}$ \\
\hline Ever in college & 0.338 & 0.345 & 0.331 & $\begin{array}{l}0.060^{*} \\
(0.033)\end{array}$ & $\begin{array}{c}0.048 \\
(0.047)\end{array}$ & $\begin{array}{l}0.079^{*} \\
(0.046)\end{array}$ \\
\hline Number of semesters & 0.973 & 1.042 & 0.893 & 0.050 & -0.119 & 0.250 \\
\hline in College & {$[1.790]$} & [1.879] & [1.687] & $(0.126)$ & $(0.185)$ & $(0.173)$ \\
\hline Ever in postsecondary & 0.549 & 0.531 & 0.571 & $0.085^{* *}$ & 0.0733 & $0.111^{* *}$ \\
\hline Education & 0.729 & 0.768 & 0.684 & $(0.035)$ & $(0.049)$ & $(0.050)$ \\
\hline \multicolumn{7}{|c|}{ Youths Were in their Mid-Twenties } \\
\hline Summary measure & & & & $\begin{array}{c}0.083^{*} \\
(0.049) \\
\end{array}$ & $\begin{array}{c}0.062 \\
(0.077) \\
\end{array}$ & $\begin{array}{c}0.112 \\
(0.077) \\
\end{array}$ \\
\hline $\begin{array}{l}\text { Obtained a bachelor’s } \\
\text { Degree }\end{array}$ & 0.020 & 0.005 & 0.038 & $\begin{array}{c}0.011 \\
(0.011)\end{array}$ & $\begin{array}{c}0.014 \\
(0.011)\end{array}$ & $\begin{array}{l}0.005 \\
(0.02)\end{array}$ \\
\hline $\begin{array}{l}\text { Obtained a bachelor's or } \\
\text { associate degree }\end{array}$ & 0.071 & 0.062 & 0.082 & $\begin{array}{l}-0.003 \\
(0.018)\end{array}$ & $\begin{array}{l}-0.006 \\
(0.023)\end{array}$ & $\begin{array}{c}0.001 \\
(0.028)\end{array}$ \\
\hline $\begin{array}{l}\text { Number of semesters in } \\
\text { College }\end{array}$ & $\begin{array}{r}1.62 \\
{[3.40]}\end{array}$ & 1.66 & 1.56 & 0.148 & -0.113 & 0.460 \\
\hline $\begin{array}{l}\text { Completed } 2 \text { years of } \\
\text { college or training }\end{array}$ & 0.301 & 0.285 & 0.320 & $\begin{array}{l}0.070 * * \\
(0.033)\end{array}$ & $\begin{array}{l}0.080 * \\
(0.045)\end{array}$ & $\begin{array}{c}0.069 \\
(0.048)\end{array}$ \\
\hline Ever in college & 0.377 & 0.392 & 0.358 & $\begin{array}{c}0.043 \\
(0.033)\end{array}$ & $\begin{array}{l}-0.006 \\
(0.046)\end{array}$ & $\begin{array}{c}0.101^{* * \dagger} \\
(0.047)\end{array}$ \\
\hline $\begin{array}{l}\text { Ever in post-secondary } \\
\text { Education }\end{array}$ & 0.558 & 0.541 & 0.579 & $\begin{array}{l}0.074 * * \\
(0.034)\end{array}$ & $\begin{array}{l}0.089 * \\
(0.047)\end{array}$ & $\begin{array}{c}0.070 \\
(0.050)\end{array}$ \\
\hline
\end{tabular}

Notes: See notes on Table 3. Post-secondary education includes two- and four-year college, vocational or technical school, and the armed forces. 
TABLE 5. TReAtment Effect on Employment Outcomes By Predicted Drug Use at Age 19

\begin{tabular}{|c|c|c|c|c|c|c|}
\hline & \multicolumn{3}{|c|}{ CONTROL MEANS } & \multicolumn{3}{|c|}{ TREATMENT-CONTROL } \\
\hline & Full sample & Low-risk & High-risk & Full sample & Low-risk & High-risk \\
\hline OUTCOMES & & & & $\begin{array}{c}\text { Full set of } \\
\text { controls }\end{array}$ & $\begin{array}{c}\text { Full set of } \\
\text { controls }\end{array}$ & $\begin{array}{c}\text { Full set of } \\
\text { controls }\end{array}$ \\
\hline & (1) & $(2)$ & (3) & $(4)$ & (5) & (6) \\
\hline \multicolumn{7}{|c|}{ Youths Were in their Early Twenties } \\
\hline Summary measure & & & & $\begin{array}{l}-0.102 * \\
(0.058)\end{array}$ & $\begin{array}{l}-0.205^{* * *} \\
(0.078)\end{array}$ & $\begin{array}{l}0.017 \dagger \\
(0.084)\end{array}$ \\
\hline Has a job & 0.730 & 0.768 & 0.686 & $\begin{array}{l}-0.042 \\
(0.033)\end{array}$ & $\begin{array}{c}-0.115^{* *} \\
(0.046)\end{array}$ & $\begin{array}{l}0.047 \dagger \dagger \\
(0.048)\end{array}$ \\
\hline Has a full-time job & 0.575 & 0.614 & 0.532 & $\begin{array}{c}-0.089 * * \\
(0.036)\end{array}$ & $\begin{array}{c}-0.134 * * * \\
(0.049)\end{array}$ & $\begin{array}{l}-0.044 \\
(0.052)\end{array}$ \\
\hline $\begin{array}{l}\text { Has a full-time job } \\
\text { with health insurance }\end{array}$ & 0.404 & 0.448 & 0.353 & $\begin{array}{l}-0.059^{*} \\
(0.035)\end{array}$ & $\begin{array}{l}-0.121^{* *} \\
(0.049)\end{array}$ & $\begin{array}{r}0.0024 \dagger \\
(0.051)\end{array}$ \\
\hline $\begin{array}{l}\text { Attending postsecondary } \\
\text { education or working }\end{array}$ & 0.809 & 0.836 & 0.776 & $\begin{array}{l}-0.006 \\
(0.029)\end{array}$ & $\begin{array}{l}-0.052 \\
(0.040)\end{array}$ & $\begin{array}{l}0.055+\dagger \\
(0.042)\end{array}$ \\
\hline $\begin{array}{l}\text { Usual hours worked } \\
\text { per week at main job }\end{array}$ & $\begin{array}{c}28.17 \\
{[19.98]}\end{array}$ & $\begin{array}{c}30.324 \\
{[19.854]}\end{array}$ & $\begin{array}{c}25.75 \\
{[19.907]}\end{array}$ & $\begin{array}{l}-1.528 \\
(2.093)\end{array}$ & $\begin{array}{l}-5.091 * * \\
(2.054)\end{array}$ & $\begin{array}{l}1.095 \dagger \dagger \\
(2.075)\end{array}$ \\
\hline Hourly wage at main & 7.57 & 7.625 & 7.561 & -0.274 & -0.804 & 0.296 \\
\hline Job & [12.15] & {$[5.952]$} & [5.627] & $(0.493)$ & $(0.777)$ & $(0.561)$ \\
\hline \multicolumn{7}{|c|}{ Youths Were in their Mid-Twenties } \\
\hline Summary measure & & & & $\begin{array}{c}0.011 \\
(0.054) \\
\end{array}$ & $\begin{array}{c}-0.026 \\
(0.075) \\
\end{array}$ & $\begin{array}{l}0.0566 \\
(0.080) \\
\end{array}$ \\
\hline Has a job & 0.707 & 0.737 & 0.669 & $\begin{array}{c}0.007 \\
(0.033)\end{array}$ & $\begin{array}{l}-0.0180 \\
(0.044)\end{array}$ & $\begin{array}{l}0.0397 \\
(0.049)\end{array}$ \\
\hline Has a full-time job & 0.553 & 0.593 & 0.503 & $\begin{array}{c}0.013 \\
(0.035)\end{array}$ & $\begin{array}{l}-0.015 \\
(0.048)\end{array}$ & $\begin{array}{c}0.048 \\
(0.052)\end{array}$ \\
\hline $\begin{array}{l}\text { Has a job with } \\
\text { health insurance }\end{array}$ & 0.491 & 0.531 & 0.442 & $\begin{array}{l}-0.004 \\
(0.036)\end{array}$ & $\begin{array}{l}-0.037 \\
(0.049)\end{array}$ & $\begin{array}{c}0.045 \\
(0.053)\end{array}$ \\
\hline $\begin{array}{l}\text { Hourly wage at } \\
\text { main job (dollars) }\end{array}$ & $\begin{array}{c}9.36 \\
{[15.97]}\end{array}$ & $\begin{array}{c}9.89 \\
{[14.42]}\end{array}$ & $\begin{array}{c}8.72 \\
{[17.72]}\end{array}$ & $\begin{array}{l}-0.671 \\
(1.008)\end{array}$ & $\begin{array}{l}-0.622 \\
(1.568)\end{array}$ & $\begin{array}{l}-1.185 \\
(1.610)\end{array}$ \\
\hline $\begin{array}{l}\text { Usual hours worked } \\
\text { per week at main job }\end{array}$ & $\begin{array}{c}27.53 \\
{[20.656]}\end{array}$ & $\begin{array}{c}29.25 \\
{[20.82]}\end{array}$ & $\begin{array}{c}25.43 \\
{[20.32]}\end{array}$ & $\begin{array}{c}0.511 \\
(1.452)\end{array}$ & $\begin{array}{l}-0.569 \\
(2.003)\end{array}$ & $\begin{array}{c}1.788 \\
(2.102)\end{array}$ \\
\hline $\begin{array}{l}\text { Total earnings in past } \\
12 \text { Months (dollars) }\end{array}$ & $\begin{array}{c}13,427 \\
{[13,291]}\end{array}$ & $\begin{array}{r}14,310 \\
{[12,635]}\end{array}$ & $\begin{array}{c}12,432 \\
{[14,027]}\end{array}$ & $\begin{array}{c}731.0 \\
(1,121)\end{array}$ & $\begin{array}{c}863.7 \\
(1,647)\end{array}$ & $\begin{array}{c}678.3 \\
(1,461)\end{array}$ \\
\hline
\end{tabular}

Notes: See notes on Table 3. No information on employment was collected when youths were in their late-teens. Earnings are coded as zero if the person is reported not working. This measure of earnings is one of realized earnings and is frequently used in the literature, despite being a crude measure of productivity—since earnings are only observed for employed individuals. 
TABLE 6. TReAtment EfFect on Risky Behaviors By Predicted Drug Use At Age 19

\begin{tabular}{|c|c|c|c|c|c|c|}
\hline & \multicolumn{2}{|c|}{ CONTROL MEANS } & \multicolumn{4}{|c|}{ TREATMENT-CONTROL } \\
\hline & Full sample & Low-risk & High-risk & Full sample & Low-risk & High-risk \\
\hline & & & & $\begin{array}{l}\text { Full set of } \\
\text { controls }\end{array}$ & $\begin{array}{l}\text { Full set of } \\
\text { controls }\end{array}$ & $\begin{array}{c}\text { Full set of } \\
\text { controls }\end{array}$ \\
\hline OUTCOMES & (1) & $(2)$ & (3) & (5) & (6) & $(7)$ \\
\hline \multicolumn{7}{|c|}{ Youths Were in their Late Teens } \\
\hline Summary measure & & & & $\begin{array}{c}-0.031 \\
(0.039)\end{array}$ & $\begin{array}{c}-0.162 * * * \\
(0.052)\end{array}$ & $\begin{array}{c}0.102 * \dagger \dagger \dagger \\
(0.058)\end{array}$ \\
\hline $\begin{array}{l}\text { Binge drinking in the } \\
\text { past } 30 \text { days }\end{array}$ & 0.188 & 0.162 & 0.218 & $\begin{array}{c}0.035 \\
(0.027)\end{array}$ & $\begin{array}{c}0.122^{* * *} \\
(0.039)\end{array}$ & $\begin{array}{c}-0.061 \dagger \dagger \dagger \\
(0.039)\end{array}$ \\
\hline $\begin{array}{l}\text { Used any illegal drug } \\
\text { in the past } 30 \text { days }\end{array}$ & 0.270 & 0.177 & 0.376 & $\begin{array}{c}0.063 * * \\
(0.031)\end{array}$ & $\begin{array}{c}0.165^{* * *} \\
(0.040)\end{array}$ & $\begin{array}{c}-0.051 \dagger \dagger \dagger \\
(0.047)\end{array}$ \\
\hline $\begin{array}{l}\text { Committed a crime in } \\
\text { past } 12 \text { months }\end{array}$ & 0.284 & 0.246 & 0.326 & $\begin{array}{c}0.024 \\
(0.031)\end{array}$ & $\begin{array}{l}0.095^{* *} \\
(0.041)\end{array}$ & $\begin{array}{c}-0.041 \dagger \dagger \\
(0.045)\end{array}$ \\
\hline $\begin{array}{l}\text { Ever arrested or } \\
\text { charged }\end{array}$ & 0.276 & 0.263 & 0.291 & $\begin{array}{l}-0.035 \\
(0.029)\end{array}$ & $\begin{array}{l}-0.008 \\
(0.039)\end{array}$ & $\begin{array}{l}-0.053 \\
(0.043)\end{array}$ \\
\hline $\begin{array}{l}\text { Have first child before } \\
\text { age } 18\end{array}$ & 0.240 & 0.230 & 0.251 & $\begin{array}{l}-0.027 \\
(0.028) \\
\end{array}$ & $\begin{array}{l}-0.024 \\
(0.038) \\
\end{array}$ & $\begin{array}{l}-0.030 \\
(0.042) \\
\end{array}$ \\
\hline \multicolumn{7}{|c|}{ Youths Were in their Early Twenties } \\
\hline Summary measure & & & & $\begin{array}{c}0.012 \\
(0.035) \\
\end{array}$ & $\begin{array}{c}-0.009 \\
(0.046)\end{array}$ & $\begin{array}{c}0.033 \\
(0.054)\end{array}$ \\
\hline $\begin{array}{l}\text { Binge drinking in the } \\
\text { past } 30 \text { days }\end{array}$ & 0.293 & 0.326 & 0.256 & $\begin{array}{l}-0.041 \\
(0.032)\end{array}$ & $\begin{array}{l}-0.0742^{*} \\
(0.0449)\end{array}$ & $\begin{array}{l}-0.010 \\
(0.045)\end{array}$ \\
\hline $\begin{array}{l}\text { Used any illegal drug } \\
\text { in the past } 30 \text { days }\end{array}$ & 0.159 & 0.113 & 0.212 & $\begin{array}{l}-0.044^{*} \\
(0.025)\end{array}$ & $\begin{array}{l}0.00251 \\
(0.0307)\end{array}$ & $\begin{array}{c}-0.084^{* *} \\
(0.041)\end{array}$ \\
\hline $\begin{array}{l}\text { Committed a crime in } \\
\text { past } 3 \text { months }\end{array}$ & 0.081 & 0.056 & 0.109 & $\begin{array}{l}-0.011 \\
(0.019)\end{array}$ & $\begin{array}{c}0.0219 \\
(0.0243)\end{array}$ & $\begin{array}{l}-0.048 \dagger \\
(0.030)\end{array}$ \\
\hline $\begin{array}{l}\text { Arrested or charged in } \\
\text { past } 3 \text { months }\end{array}$ & 0.042 & 0.034 & 0.051 & $\begin{array}{c}0.003 \\
(0.015)\end{array}$ & $\begin{array}{c}0.010 \\
(0.018)\end{array}$ & $\begin{array}{l}-0.004 \\
(0.024)\end{array}$ \\
\hline $\begin{array}{l}\text { Have first child before } \\
\text { age } 18\end{array}$ & 0.148 & 0.141 & 0.157 & $\begin{array}{c}0.030 \\
(0.026)\end{array}$ & $\begin{array}{c}0.009 \\
(0.035)\end{array}$ & $\begin{array}{c}0.061 \\
(0.039)\end{array}$ \\
\hline Currently on welfare & 0.184 & 0.183 & 0.186 & $\begin{array}{c}0.032 \\
(0.028) \\
\end{array}$ & $\begin{array}{c}0.018 \\
(0.038)\end{array}$ & $\begin{array}{l}0.0297 \\
(0.042)\end{array}$ \\
\hline \multicolumn{7}{|c|}{ Youths Were in their Mid-Twenties } \\
\hline Summary measure & & & & $\begin{array}{c}-0.078 * * \\
(0.035) \\
\end{array}$ & $\begin{array}{c}-0.085^{*} \\
(0.047) \\
\end{array}$ & $\begin{array}{l}-0.065 \\
(0.055) \\
\end{array}$ \\
\hline $\begin{array}{l}\text { Binge drinking in the } \\
\text { past } 30 \text { days }\end{array}$ & 0.283 & 0.325 & 0.243 & $\begin{array}{c}0.012 \\
(0.031)\end{array}$ & $\begin{array}{l}-0.005 \\
(0.042)\end{array}$ & $\begin{array}{c}0.046 \\
(0.046)\end{array}$ \\
\hline $\begin{array}{l}\text { Used any illegal drug } \\
\text { in the past } 30 \text { days }\end{array}$ & 0.120 & 0.088 & 0.160 & $\begin{array}{c}0.001 \\
(0.022)\end{array}$ & $\begin{array}{c}0.038 \\
(0.030)\end{array}$ & $\begin{array}{l}-0.050 \dagger \\
(0.036)\end{array}$ \\
\hline $\begin{array}{l}\text { Committed a crime in } \\
\text { past } 3 \text { months }\end{array}$ & 0.020 & 0.015 & 0.026 & $\begin{array}{c}0.017 \\
(0.012)\end{array}$ & $\begin{array}{c}0.008 \\
(0.014)\end{array}$ & $\begin{array}{c}0.028 \\
(0.020)\end{array}$ \\
\hline $\begin{array}{l}\text { Arrested or charged in } \\
\text { past } 2 \text { years }\end{array}$ & 0.051 & 0.041 & 0.064 & $\begin{array}{l}0.044 * * \\
(0.018)\end{array}$ & $\begin{array}{l}0.054 * * \\
(0.025)\end{array}$ & $\begin{array}{c}0.032 \\
(0.028)\end{array}$ \\
\hline $\begin{array}{l}\text { Have first child before } \\
\text { age } 18\end{array}$ & 0.162 & 0.160 & 0.166 & $\begin{array}{c}0.014 \\
(0.026)\end{array}$ & $\begin{array}{l}-0.009 \\
(0.035)\end{array}$ & $\begin{array}{c}0.036 \\
(0.040)\end{array}$ \\
\hline Currently on welfare & 0.220 & 0.201 & 0.244 & $\begin{array}{c}0.033 \\
(0.029)\end{array}$ & $\begin{array}{c}0.054 \\
(0.039)\end{array}$ & $\begin{array}{l}0.0026 \\
(0.045)\end{array}$ \\
\hline
\end{tabular}

Notes: See notes on Table 3. 
TABLE 7. Peer Effects By Predicted Drug Use at Age 19

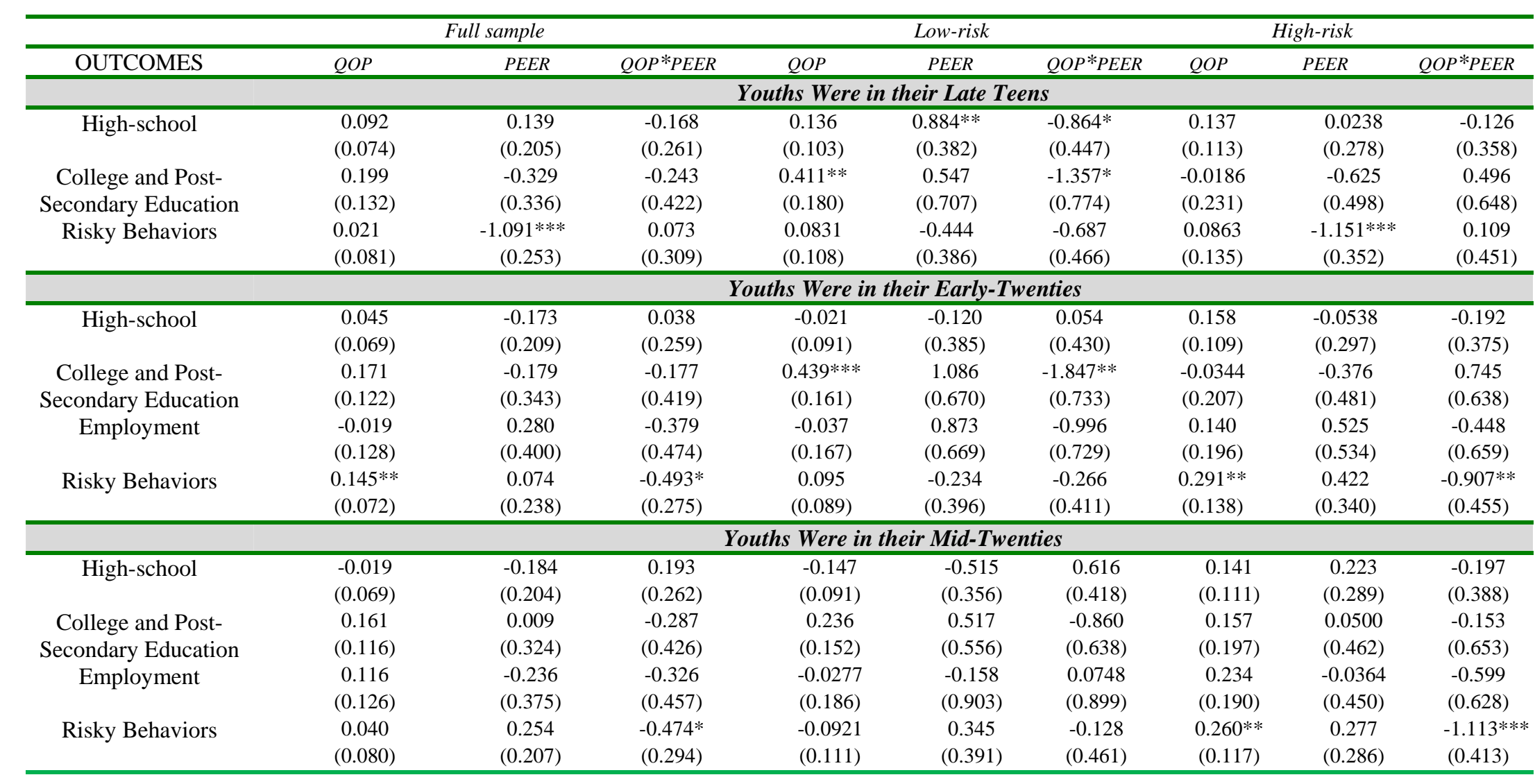

Notes: See notes on Table 3. In addition to the covariates described in Table 3, the specifications from this Table include a peers' variable and a variable interacting peers' effects and the

treatment dummy. The peers' variable is measured as follows: for each individual we estimated the proportion of students within the same school, treatment status, sex, and race, that reported

doing drugs at age 19 
Online Appendix:

School, Drugs: Closing the Gap

Evidence from a Randomized Trial in the United States

By Núria Rodríguez-Planas 
TABLE A.1

QOP’s DEVElopmental ACTIVITIES, COMMUNity SERVICE ACTIVITIES AND EDUCATIONAL SERVICES

\begin{tabular}{cc}
\hline Activity & Examples of such types of activities \\
\hline Developmental & $\begin{array}{c}\text { Life skills activities/ discussion topics (such as, family planning, nutrition, personal hygiene, } \\
\text { managing anger, avoiding drug behaviors, among others); pre-employment training; cultural } \\
\text { activities; and recreational activities. }\end{array}$ \\
Educational services & $\begin{array}{c}\text { Visits to the residents of a local nursing home, or volunteering at a local food bank. } \\
\text { Academic assessment, development of individualized education plans, one-on-one tutoring, } \\
\text { and computer-assisted instruction in specific coursework as well as basic reading and } \\
\text { mathematics. }\end{array}$ \\
$\begin{array}{c}\text { Making the youth aware of, and helping them plan for, college and other } \\
\text { post-secondary education or training. }\end{array}$
\end{tabular}

TABLE A.2

Determinants of Social Problems in the Control Group, By Gender

\begin{tabular}{|c|c|c|}
\hline & \multicolumn{2}{|c|}{ Drug use } \\
\hline & Males & Females \\
\hline LHS variable means & 0.335 & 0.192 \\
\hline \multicolumn{3}{|c|}{ Age when entering $9^{\text {th }}$ grade } \\
\hline 14 & $\begin{array}{c}-0.692 \\
(0.556)\end{array}$ & $\begin{array}{c}0.401 \\
(0.612)\end{array}$ \\
\hline$>14$ & $\begin{array}{l}-0.461 \\
(0.596)\end{array}$ & $\begin{array}{c}0.020 \\
(0.806)\end{array}$ \\
\hline \multicolumn{3}{|l|}{ Rank based on $8^{\text {th }}$ grade } \\
\hline Middle third & $\begin{array}{c}0.367 \\
(0.376)\end{array}$ & $\begin{array}{c}0.048 \\
(0.569)\end{array}$ \\
\hline Top third & $\begin{array}{c}-0.045 \\
(0.401)\end{array}$ & $\begin{array}{c}-0.061 \\
(0.545)\end{array}$ \\
\hline Black & $\begin{array}{c}-0.158 \\
(0.862)\end{array}$ & $\begin{array}{c}0.706 \\
(1.078)\end{array}$ \\
\hline Hispanic & $\begin{array}{c}-0.330 \\
(0.743)\end{array}$ & $\begin{array}{c}-0.763 \\
(1.057)\end{array}$ \\
\hline Observations & 209 & 172 \\
\hline Pseudo R-squared & 0.075 & 0.060 \\
\hline
\end{tabular}

Notes: The table reports logit estimates. The estimates in this table are constructed using the sample of control group youths only. School dummies are included in the specification. 
TABLE A.3. Participation IN QOP Activities By PREDICTED Drug Use AT Age 19

\begin{tabular}{|c|c|c|c|c|c|c|c|c|c|}
\hline & \multirow[b]{2}{*}{$\begin{array}{c}\text { Cumulative } \\
\text { Years } \\
1 \text { through } 4\end{array}$} & \multirow[b]{2}{*}{ Year 1} & \multirow[b]{2}{*}{ Year 4} & \multicolumn{3}{|c|}{ Low-risk } & \multicolumn{3}{|c|}{ High-risk } \\
\hline & & & & $\begin{array}{c}\text { Cumulative } \\
\text { Years } \\
1 \text { through } \\
4\end{array}$ & Year 1 & Year 4 & $\begin{array}{c}\text { Cumulative } \\
\text { Years } \\
1 \text { through } \\
4\end{array}$ & Year 1 & Year 4 \\
\hline Average Number of Hours & 886 & 279 & 125 & 877 & 290 & 117 & 896 & 267 & 133 \\
\hline Average Hours on Educational Activities & 245 & 97 & 26 & 247 & 101 & 23 & 244 & 92 & 30 \\
\hline $\begin{array}{l}\text { Average Hours on Developmental } \\
\text { Activities }\end{array}$ & 302 & 114 & 27 & 110 & 39 & 13 & 108 & 36 & 16 \\
\hline $\begin{array}{l}\text { Average Hours on Community Service } \\
\text { Activities }\end{array}$ & 109 & 37 & 14 & 298 & 114 & 22 & 306 & 113 & 32 \\
\hline No Hours of Participation (percent) & 1 & 1 & 40 & 1 & 1 & 36 & 1 & 1 & 44 \\
\hline More Than 100 Hours (percent) & 88 & 74 & 22 & 87 & 73 & 17 & 89 & 77 & 27 \\
\hline More Than 375 Hours (percent) & 60 & 25 & 9 & 57 & 26 & 8 & 63 & 24 & 12 \\
\hline More Than 750 Hours (percent) & 37 & 7 & 4 & 34 & 9 & 4 & 40 & 5 & 4 \\
\hline More Than 1,500 Hours (percent) & 17 & 0 & 2 & 17 & 0 & 1 & 17 & 0 & 2 \\
\hline Total Amount Earned (dollars) & $\$ 1,122$ & $\$ 349$ & $\$ 156$ & $\$ 1,103$ & $\$ 363$ & $\$ 146$ & $\$ 1,142$ & $\$ 334$ & $\$ 167$ \\
\hline
\end{tabular}

Note: Because QOP services in Period 5 differed substantially from those of the first four periods, we report hours over the first four periods. In Period 5, QOP offered enrollees who had graduated from high school only mentoring services, and hours spent being mentored were not recorded. 
TABLE A.4. MEAn EfFect Sizes for Summary Measures of Outcomes Clustering Standard ERrors AT THE SCHOOL LEVEL

\begin{tabular}{|c|c|c|c|c|}
\hline & \multicolumn{4}{|c|}{ TREATMENT-CONTROL } \\
\hline & & & \multicolumn{2}{|c|}{$\begin{array}{c}\text { CLUSTERED STANDARD } \\
\text { ERRORS }\end{array}$} \\
\hline & Low-risk & High-risk & Low-risk & High-risk \\
\hline OUTCOMES & $\begin{array}{c}\text { Full set of } \\
\text { controls }\end{array}$ & $\begin{array}{c}\text { Full set of } \\
\text { controls }\end{array}$ & $\begin{array}{c}\text { Full set of } \\
\text { controls }\end{array}$ & $\begin{array}{c}\text { Full set of } \\
\text { controls }\end{array}$ \\
\hline Youths Were in their Late Teens & (1) & (2) & (3) & $(4)$ \\
\hline High-school & $\begin{array}{l}0.0031 \\
(0.049)\end{array}$ & $\begin{array}{l}0.099 * * \\
(0.047)\end{array}$ & $\begin{array}{l}0.0031 \\
(0.041)\end{array}$ & $\begin{array}{l}0.099 * * \\
(0.044)\end{array}$ \\
\hline College and Post-Secondary & $\begin{array}{c}0.094 \\
(0.082)\end{array}$ & $\begin{array}{c}0.129 \\
(0.084)\end{array}$ & $\begin{array}{c}0.094 \\
(0.062)\end{array}$ & $\begin{array}{c}0.129 \\
(0.082)\end{array}$ \\
\hline Risky Behaviors & $\begin{array}{c}-0.162^{* * *} \\
(0.052)\end{array}$ & $\begin{array}{c}0.102^{* \dagger \dagger \dagger} \\
(0.058)\end{array}$ & $\begin{array}{c}-0.162^{* * *} \\
(0.037)\end{array}$ & $\begin{array}{c}0.102 * * \dagger \dagger \dagger \\
(0.034)\end{array}$ \\
\hline \multicolumn{5}{|l|}{ Youths Were in their Early Twenties } \\
\hline High-school & $\begin{array}{l}-0.021 \\
(0.043)\end{array}$ & $\begin{array}{c}0.101^{* * \dagger} \\
(0.048)\end{array}$ & $\begin{array}{l}-0.021 \\
(0.046)\end{array}$ & $\begin{array}{l}0.101^{*} \\
(0.046)\end{array}$ \\
\hline College and Post-Secondary & $\begin{array}{c}0.061 \\
(0.086)\end{array}$ & $\begin{array}{l}0.177^{* *} \\
(0.082)\end{array}$ & $\begin{array}{c}0.061 \\
(0.084)\end{array}$ & $\begin{array}{l}0.177 * \\
(0.082)\end{array}$ \\
\hline Employment & $\begin{array}{c}-0.205^{* * *} \\
(0.078)\end{array}$ & $\begin{array}{l}0.017 \dagger \\
(0.084)\end{array}$ & $\begin{array}{l}-0.205 \\
(0.121)\end{array}$ & $\begin{array}{l}0.017 \dagger \\
(0.051)\end{array}$ \\
\hline Risky Behaviors & $\begin{array}{l}-0.009 \\
(0.046)\end{array}$ & $\begin{array}{c}0.033 \\
(0.054)\end{array}$ & $\begin{array}{l}-0.009 \\
(0.048)\end{array}$ & $\begin{array}{c}0.033 \\
(0.041)\end{array}$ \\
\hline \multicolumn{5}{|l|}{ Youths Were in their Mid-Twenties } \\
\hline High-school & $\begin{array}{l}-0.038 \\
(0.042)\end{array}$ & $\begin{array}{c}0.085^{*} \dagger \dagger \\
(0.044)\end{array}$ & $\begin{array}{l}-0.038 \\
(0.046)\end{array}$ & $\begin{array}{l}0.085^{*} \\
(0.043)\end{array}$ \\
\hline College and Post-Secondary & $\begin{array}{c}0.063 \\
(0.061)\end{array}$ & $\begin{array}{c}0.112 \\
(0.077)\end{array}$ & $\begin{array}{c}0.063 \\
(0.039)\end{array}$ & $\begin{array}{c}0.112 \\
(0.064)\end{array}$ \\
\hline Employment & $\begin{array}{l}-0.026 \\
(0.075)\end{array}$ & $\begin{array}{c}0.057 \\
(0.080)\end{array}$ & $\begin{array}{l}-0.026 \\
(0.048)\end{array}$ & $\begin{array}{c}0.057 \\
(0.075)\end{array}$ \\
\hline Risky Behaviors & $\begin{array}{l}-0.085^{*} \\
(0.047)\end{array}$ & $\begin{array}{l}-0.065 \\
(0.055)\end{array}$ & $\begin{array}{l}-0.085^{*} \\
(0.046)\end{array}$ & $\begin{array}{l}-0.065 \\
(0.054)\end{array}$ \\
\hline
\end{tabular}

Notes: The table reports estimates of treatment effects on the dependent variables indicated in row headings. Robust standard errors are reported in parentheses. "Full set of controls" includes school dummies, an indicator for being male, an indicator for being 14 years old when entering ninth grade, an indicator for being over age 14 when entering ninth grade, an indicator for being in the middle third of the eighth-grade GPA distribution, an indicator for being in the top third of the eightgrade GPA distribution, an indicator for being black and an indicator for being Hispanic.

*, ** Estimate significantly different from zero at the $90 \%$, or $95 \%$ confidence level. 
TABLE A.5. Mean Effect Sizes for Summary Measures of Outcomes Using SAme Response Rates ACROSS TREATMENT

\begin{tabular}{|c|c|c|c|c|}
\hline & \multicolumn{4}{|c|}{ TREATMENT-CONTROL } \\
\hline & & & \multicolumn{2}{|c|}{$\begin{array}{c}\text { SAME RESPONSE RATE } \\
\text { TREATMENT AND CONTROL }\end{array}$} \\
\hline & Low-risk & High-risk & Low-risk & High-risk \\
\hline OUTCOMES & $\begin{array}{l}\text { Full set of } \\
\text { controls }\end{array}$ & $\begin{array}{l}\text { Full set of } \\
\text { controls }\end{array}$ & $\begin{array}{l}\text { Full set of } \\
\text { controls }\end{array}$ & $\begin{array}{l}\text { Full set of } \\
\text { controls }\end{array}$ \\
\hline Youths Were in their Late Teens & $(1)$ & $(2)$ & (3) & (4) \\
\hline High-school & $\begin{array}{l}0.0031 \\
(0.049)\end{array}$ & $\begin{array}{c}0.099 * * \\
(0.047)\end{array}$ & $\begin{array}{l}-0.003 \\
(0.051)\end{array}$ & $\begin{array}{c}0.149 * * * \\
(0.049)\end{array}$ \\
\hline College and Post-Secondary & $\begin{array}{c}0.094 \\
(0.082)\end{array}$ & $\begin{array}{c}0.129 \\
(0.084)\end{array}$ & $\begin{array}{c}0.073 \\
(0.083)\end{array}$ & $\begin{array}{l}0.153^{*} \\
(0.089)\end{array}$ \\
\hline Risky Behaviors & $\begin{array}{r}-0.162 * * * \\
(0.052)\end{array}$ & $\begin{array}{l}0.102 * \dagger \dagger \dagger \\
(0.058)\end{array}$ & $\begin{array}{c}-0.161^{* * *} \\
(0.053)\end{array}$ & $\begin{array}{c}0.127 * * \dagger \dagger \dagger \\
(0.060)\end{array}$ \\
\hline \multicolumn{5}{|l|}{ Youths Were in their Early Twenties } \\
\hline High-school & $\begin{array}{l}-0.021 \\
(0.043)\end{array}$ & $\begin{array}{c}0.101 * * \dagger \\
(0.048)\end{array}$ & $\begin{array}{l}-0.034 \\
(0.043)\end{array}$ & $\begin{array}{c}0.091 * \dagger \dagger \\
(0.049)\end{array}$ \\
\hline College and Post-Secondary & $\begin{array}{c}0.061 \\
(0.086)\end{array}$ & $\begin{array}{c}0.177^{* *} \\
(0.082)\end{array}$ & $\begin{array}{c}0.067 \\
(0.089)\end{array}$ & $\begin{array}{l}0.180 * * \\
(0.087)\end{array}$ \\
\hline Employment & $\begin{array}{c}-0.205^{* * *} \\
(0.078)\end{array}$ & $\begin{array}{l}0.017 \dagger \\
(0.084)\end{array}$ & $\begin{array}{c}-0.169 * * \\
(0.081)\end{array}$ & $\begin{array}{l}0.050 \dagger \\
(0.086)\end{array}$ \\
\hline Risky Behaviors & $\begin{array}{c}-0.009 \\
(0.046)\end{array}$ & $\begin{array}{c}0.033 \\
(0.054)\end{array}$ & $\begin{array}{c}-0.009 \\
(0.046)\end{array}$ & $\begin{array}{c}0.014 \\
(0.058)\end{array}$ \\
\hline \multicolumn{5}{|l|}{ Youths Were in their Mid-Twenties } \\
\hline High-school & $\begin{array}{l}-0.038 \\
(0.042)\end{array}$ & $\begin{array}{l}0.085^{* \dagger \dagger} \\
(0.044)\end{array}$ & $\begin{array}{l}-0.059 \\
(0.049)\end{array}$ & $\begin{array}{l}0.076 \dagger \dagger \\
(0.052)\end{array}$ \\
\hline College and Post-Secondary & $\begin{array}{c}0.063 \\
(0.061)\end{array}$ & $\begin{array}{c}0.112 \\
(0.077)\end{array}$ & $\begin{array}{c}0.059 \\
(0.064)\end{array}$ & $\begin{array}{l}0.143 * \\
(0.082)\end{array}$ \\
\hline Employment & $\begin{array}{l}-0.026 \\
(0.075)\end{array}$ & $\begin{array}{c}0.057 \\
(0.080)\end{array}$ & $\begin{array}{c}-0.019 \\
(0.077)\end{array}$ & $\begin{array}{c}0.081 \\
(0.083)\end{array}$ \\
\hline Risky Behaviors & $\begin{array}{l}-0.085^{*} \\
(0.047)\end{array}$ & $\begin{array}{l}-0.065 \\
(0.055)\end{array}$ & $\begin{array}{l}-0.087^{*} \\
(0.048)\end{array}$ & $\begin{array}{l}-0.074 \\
(0.058)\end{array}$ \\
\hline
\end{tabular}

Notes: Same response estimates were obtained by making the response rate equal across treatment and control groups within school and within top- or bottom-half of the predicted drug use distribution. By restricting response rates by school and risk level to be equal the sample sizes got reduced by 59 observations in the first survey, 70 observations in the second survey and 53 observations in the last survey. The table reports estimates of treatment effects on the dependent variables indicated in row headings. Robust standard errors are reported in parentheses. "Full set of controls" includes school dummies, an indicator for being male, an indicator for being 14 years old when entering ninth grade, an indicator for being over age 14 when entering ninth grade, an indicator for being in the middle third of the eighth-grade GPA distribution, an indicator for being in the top third of the eight-grade GPA distribution, an indicator for being black and an indicator for being Hispanic.

*, ** Estimate significantly different from zero at the $90 \%$, or $95 \%$ confidence level. 


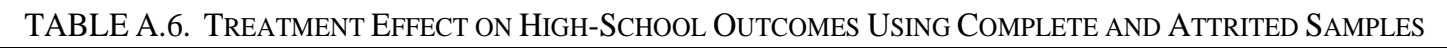

\begin{tabular}{|c|c|c|c|c|c|c|}
\hline & \multicolumn{3}{|c|}{ COMPLETE SAMPLE } & \multicolumn{3}{|c|}{ ATTRITED SAMPLE } \\
\hline & Full sample & Low-risk & High-risk & Full sample & Low-risk & High-risk \\
\hline \multirow[t]{2}{*}{ OUTCOMES } & $\begin{array}{c}\text { Full set of } \\
\text { controls }\end{array}$ & $\begin{array}{c}\text { Full set of } \\
\text { controls }\end{array}$ & $\begin{array}{c}\text { Full set of } \\
\text { controls }\end{array}$ & $\begin{array}{c}\text { Full set of } \\
\text { controls }\end{array}$ & $\begin{array}{c}\text { Full set of } \\
\text { controls }\end{array}$ & $\begin{array}{c}\text { Full set } \\
\text { of controls }\end{array}$ \\
\hline & $(1)$ & $(2)$ & (3) & $(4)$ & (5) & (6) \\
\hline \multicolumn{7}{|c|}{ Youths Were in their Late Teens } \\
\hline Obtained high-school & $0.053^{*}$ & 0.007 & $0.095^{* *}$ & 0.046 & 0.014 & $0.075^{*}$ \\
\hline Diploma & $(0.029)$ & $(0.041)$ & $(0.041)$ & $(0.031)$ & $(0.044)$ & $(0.043)$ \\
\hline Obtained a GED & -0.009 & -0.016 & -0.001 & -0.009 & -0.016 & -0.001 \\
\hline & $(0.017)$ & $(0.021)$ & $(0.028)$ & $(0.017)$ & $(0.022)$ & $(0.029)$ \\
\hline Sample size ${ }^{a}$ & 1,008 & 523 & 484 & 892 & 464 & 428 \\
\hline \multicolumn{7}{|c|}{ Youths Were in their Early Twenties } \\
\hline Obtained high-school & 0.032 & -0.045 & $0.102 * * \dagger$ & 0.031 & -0.045 & $0.101 * * \dagger \dagger$ \\
\hline Diploma & $(0.030)$ & $(0.041)$ & $(0.043)$ & $(0.033)$ & $(0.045)$ & $(0.047)$ \\
\hline Obtained a GED & 0.008 & 0.019 & -0.002 & 0.010 & 0.018 & -0.002 \\
\hline & $(0.023)$ & $(0.029)$ & $(0.038)$ & $(0.024)$ & $(0.030)$ & $(0.039)$ \\
\hline Sample size & 942 & 486 & 456 & 786 & 398 & 388 \\
\hline \multicolumn{7}{|c|}{ Youths Were in their Mid-Twenties } \\
\hline Obtained high-school & 0.021 & -0.054 & $0.097 * * \dagger$ & 0.039 & -0.049 & $0.138 * * * \dagger$ \\
\hline Diploma & $(0.030)$ & $(0.040)$ & $(0.044)$ & $(0.032)$ & $(0.045)$ & $(0.047)$ \\
\hline Obtained a GED & 0.002 & 0.012 & -0.011 & -0.016 & 0.0033 & -0.038 \\
\hline & $(0.024)$ & $(0.031)$ & $(0.039)$ & $(0.025)$ & $(0.033)$ & $(0.040)$ \\
\hline Sample size & 919 & 480 & 439 & 792 & 417 & 375 \\
\hline
\end{tabular}

Notes: The table reports estimates of treatment effects on the dependent variables indicated in row headings. Robust standard errors are reported in parentheses. "Full set of controls" includes school dummies, an indicator for being male, an indicator for being 14 years old when entering ninth grade, an indicator for being over age 14 when entering ninth grade, an indicator for being in the middle third of the eighth-grade GPA distribution, an indicator for being in the top third of the eight-grade GPA distribution, an indicator for being black and an indicator for being Hispanic.

* Estimate significantly different from zero at the $90 \%$ level.

${ }^{\text {a }}$ Sample size differs from that of Table 3 in the main paper because when estimating summary indices if an individual has a valid response to at least one component measure of an index, then any missing values for other component measures are imputed at the random assignment group mean (as in Jeffrey Kling, Jeffrey Liebman, and Lawrence Katz 2007). 